\title{
Outliers, Connectors, and Textual Periphery: John Dennis's Social Network in The Dunciad in Four Books
}

Ileana Baird

While reports on large ongoing projects involving the use of data visualizations in eighteenth-century studies have started to emerge in recent years, ${ }^{1}$ mainly due to primary texts becoming accessible through digitization processes and data-sharing initiatives, less focus has been put so far on the potential for data visualization to unveil new information about particular texts, literary or not. The reasons are quite obvious: the texts in question should be structurally or stylistically complex enough to render such an analysis valuable. In other words, looking at a text's

${ }^{1}$ Important book-length publications include Chloe Edmondson and Dan Edelstein, eds., Networks of Enlightenment: Digital Approaches to the Republic of Letters (Liverpool: Voltaire Foundation in association with Liverpool University Press, 2019); and Simon Burrows and Glenn Roe, eds., Digitizing Enlightenment: Digital Humanities and the Transformation of Eighteenth-Century Studies (Liverpool: Voltaire Foundation in association with Liverpool University Press, 2020).

I. Baird $(\bowtie)$

Zayed University, Abu Dhabi, United Arab Emirates

e-mail: ileana.baird@zu.ac.ae

(c) The Author(s) 2021

I. Baird (ed.), Data Visualization in Enlightenment Literature and

Culture, https://doi.org/10.1007/978-3-030-54913-8_8 
argument, organization, or style from a quantitative perspective-whether to identify hidden patterns of relationships among characters, map narrative trajectories, decipher obscure allusions, spot stylistic differences, or attribute authorship-requires a text that is complex or contentious enough to justify the use of forensic linguistics, stylometry, or other forms of data analysis involving quantitative methods. Unsurprisingly, such texts are rare: one example is Samuel Johnson's Dictionary, which has been recently analyzed in light of the knowledge networks it creates through the use of quotations and its role in the process of canon formation. ${ }^{2}$ Another example is Samuel Richardson's Clarissa, where the author's ability to create distinctive character writeprints has been tested through the use of machine learning techniques. ${ }^{3}$ Another text extraordinarily rich in potential is, I argue, Alexander Pope's mock-epic poem The Dunciad in Four Book (1743), whose comprehensive attack on a large number of reallife characters, sophisticated use of annotations, and multiple revisions over a period of seventeen years make it a perfect case study for quantitative analyses.

The Dunciad remains, to date, the poem with the largest number of identifiable characters in British literature: dozens of dunces inhabit its spaces creating, through the mere frequency of the names provided, the strong impression that the individuals mentioned in the poem are not important as real characters, but as pieces in an intricate mechanism of cultural reassessment. To complicate things even more, many of Pope's dunces change from one edition to another, are obscure individuals, or are difficult to identify due to the author's use of sobriquets. Moreover, because of his epic's allusive mood and playful competition between the poem and the apparatus, his dunces' affiliations and the motivations of Pope's attacks are many times unclear. Jonathan Swift's concern with the Dunciad's indecipherability ${ }^{4}$ echoes, therefore, the problems faced by current readers, who need to approach the text with a key to its social and plot networks to clarify its meanings.

\footnotetext{
${ }^{2}$ Mark Algee-Hewitt, “The Principles of Meaning: Networks of Knowledge in Johnson's Dictionary," in Edmondson and Edelstein, Networks of Enlightenment, 251-77.

${ }^{3}$ Lisa Pearl, Kristine Lu, and Anousheh Haghighi, "The Character in the Letter: Epistolary Attribution in Samuel Richardon's Clarissa," Digital Scholarship in the Humanities 32, no. 2 (2017): 355-76, https://doi.org/10.1093/llc/fqw007

4 "I have long observ'd that twenty miles from London no body understands hints, initial letter, or town-facts and passages; and in a few years not even those who live in London." See George Sherburn, ed., The Correspondence of Alexander Pope (Oxford: Oxford Clarendon Press, 1956), 2: 504-505.
} 
One solution to this dilemma is, of course, punctilious footnoting. Edmund Curll was the first one to annotate the poem in his Key to the Dunciad, published in June 1728. The Scriblerians followed suit, experimenting playfully with ersatz and pedantic footnoting in The Dunciad Variorum (1729). Inspired by the 1716 Geneva edition of Boileau's Works, Pope split his footnotes in Remarks, containing commentaries by "Modern" critics, and Imitations, containing quotes from ancient or contemporary authors whose work he admired. In the 1751 edition of Pope's Works, William Warburton introduced a third category of notes, Variations, which recorded Pope's successive revisions of The Dunciad. ${ }^{5}$ As pointed out by current criticism, Pope's use of notes served not only satirical but also historical and explanatory functions. ${ }^{6}$ They were meant to ridicule authors and critics who fell short of talent and wit, to set better examples in the "Ancients" texts, and to elucidate the context of his war with the dunces. As such, these footnotes do provide the necessary "keys" to contextualize his defamatory assaults, with only one major problem: they are utterly unreliable. The mini-narratives they provide are contradictory, incomplete, and obviously biased; they shed only the right amount of light on events to raise questions about his dunces' competence, but rarely provide the full context of these events. They involve authorial sympathies or antipathies, heated debates, and scandalous abuse; in short, they function as a lively replica of the disputes occurring in eighteenth-century coffeehouses and city streets. The motivations of The Dunciad's attacks on particular characters become, therefore, even more difficult to untangle under the weight of these "clarifications" of Pope's authorial intentions. To address this issue,

\footnotetext{
${ }^{5}$ The poem went through three major revisions, thirty-three separate editions, and about sixty impressions by 1751, the year of Warburton's posthumous edition of Pope's Works. The changes it encountered ranged from paratextual additions (footnotes, illustrations, front and back matter) to more significant revisions, such as the replacement of the initial hero of the poem, playwright Lewis Theobald, with actor and poet laureate Colley Cibber, in The Dunciad in Four Books. For details, see David L. Vander Meulen, Pope's Dunciad of 1728. A History and Facsimile (Charlottesville: University of Virginia Press, 1991), 3-72.

${ }^{6}$ Harold Weber, "The 'Garbage Heap' of Memory: At Play in Pope's Archives of Dulness," Eighteenth-Century Studies 33, no. 1 (1999): 15, https://doi.org/10.1353/ecs.1999.0060. For insightful analyses of Pope's footnotes, see also Anthony Grafton, The Footnote: A Curious History (Cambridge, MA: Harvard University Press, 1997), 23, and Chuck Zerby, The Devil's Details. A History of Footnotes (New York: Simon \& Schuster, 2002), 45-58.
} 
modern editions of the 1729 and 1743 Dunciads contain additional layers of notes to the text and to the Scriblerian footnotes themselves. ${ }^{7}$

I would like to call attention, therefore, to another way of approaching this text that could help in navigating its complicated argument: reading Pope's satire by using the new quantitative methods afforded by digital technologies. This method involves the use of social network analysis to represent the text as a collection of asserted links between various character names. Rather than focusing on clarifying information gaps and/or allusions to real life events, as the critical notes to Pope's satirical footnotes do, this approach X-rays the poem, focusing, instead, on character relationships as they emerge from both text and apparatus (front and back matter, footnotes, headpieces, illustrations). This type of analysis has different goals than untangling the poem's annotative maze: it uncovers more obscure relationships of hostility or alliance, makes evident the main targets of Pope's satire, identifies the protagonists who act as "connectors" or "outliers" in the social network of the poem, helps elucidate authorial intentions not clearly spelled out by the text or the apparatus, and suggestively illustrates the magnitude of Pope's war with his dunces. As such, this approach can augment discussions about political leanings, gender bias, promotion practices, and canon formation-all issues of paramount importance for the construction of publicness as a moral and political category at the beginning of the eighteenth century.

After a brief description of this digital project, I will focus here on the networks of relations that involved John Dennis, the most important critic of the first half of the eighteenth century and one of the most vituperative attackers of Pope's work. The analysis of Dennis's social network will shed new light on the importance Pope assigned to the critic in his satire, the competing stories told by the poem and the apparatus, and Dennis's role as a connector within the highly networked public of early eighteenthcentury London.

\footnotetext{
${ }^{7}$ I refer here to Valerie Rumbold's exemplary editions: Alexander Pope, The Dunciad in Four Books (New York: Pearson, 1999), and The Poems of Alexander Pope. Volume III: The Dunciad (1728) of The Dunciad Variorum (1729) (New York: Pearson, 2007). All the quotes used in this chapter come from the former edition.
} 


\section{Methods ANd Goals}

As a Social Sciences, Humanities and Performing Arts Network of Technological Initiatives (SHANTI) fellow at the University of Virginia, I had the opportunity of working with Rafael Alvarado, at the time Associate Director of the program, on a project involving the visualization of the fields of relations of six of Pope's dunces: Colley Cibber, the last King of Dunces, actor, theater manager, and Poet Laureate to King George II; Edmund Curll, notorious bookseller and publisher epitomizing the unscrupulous rush for profit of the print market of the time; Eliza Haywood, remarkable actress, novelist, playwright, and periodical publisher; John "Orator" Henley, a famous cleric and one of the most controversial public figures of Pope's time; John Dennis, the leading critic of the period; and Giles Jacob, legal author with literary ambitions who consistently supported Dennis in his attacks against Pope. These dunces were selected based on their representative value: they all inhabit key areas of the political, cultural, and religious life of early eighteenthcentury London.

The text I used was the 1743 edition of the poem, The Dunciad in Four Books, which contains Pope's latest changes in characters and textual revisions. I started by capturing all the information relevant to each of these six characters in a spreadsheet indicating the dunce's name, his or her location within the text (i.e., the poem or the apparatus), the textual reference to the dunce (e.g., "and all the mighty Mad in Dennis rage ..."), the individuals the character is linked to, the nature of their affiliation (similarity, dissimilarity, character attacked, or character defended), alternative names or references used by the poet to identify the character (i.e., Dennis is also referred to as "Furius" or "a dry old gentleman"), and a brief description of the character's role within the poem (critic, poet, journalist, etc.) (Table 8.1). When the protagonist is mentioned in the main text, the exact quote is recorded in bold to account for the number of instances he or she appears in the poem versus the apparatus (e.g., in Dennis's case, the ratio is 3:92). By using a simple script (Perl), we then converted this spreadsheet into a series of graph data structures that could be interpreted by a graph visualizer. 
Next, we generated images of the social networks in which these characters were involved by using two tools: GraphViz and ShivaGraph. GraphViz is an open source visualization software that creates topological graphs from sets of dyadic relations. Each graph represents a view of the social network data expressed directly and indirectly in Pope's Dunciad, as a neato, circo, or dot algorithm. ${ }^{8}$ In the GraphViz visualizations, the relationships among characters are color-coded: green edges indicate similarity (i.e., Eliza Haywood is described as similar to classicist author and translator Anne Tanneguy-Le Fèvre Dacier ${ }^{9}$ ), dotted red edges indicate dissimilarity (i.e., Besaleel Morris, William Bond, and John Durant Breval are less skilled than William Congreve, Joseph Addison, and Matthew Prior, whom they try to emulate), red edges indicate character attacked (i.e., Dennis attacked Pope), and dotted green edges indicate character defended (i.e., Giles Jacob defended Dennis during his quarrel with Pope). ${ }^{10}$ Shiva stands for SHANTI Interactive Visualization Application. This application can be used to create charts, graphs, tables, maps, and other data representations that help visualize large sets of networks and navigate through them as through a map. The Shiva graph shows

\footnotetext{
${ }^{8}$ Neato are spring-model layouts of undirected graphs (i.e., graphs in which all nodes are connected, and the edges are bidirectional); this is the default tool to use if a graph is not too large (about 100 nodes) and when trying to identify high or low energy configurations (in our case, main nodes/connectors vs. peripheral characters). Circo are circular layouts of undirected graphs; they are very useful in highlighting relationships between agents/objects or positions within a network (in our case, the main targets of Pope's attacks, or the poem's "hall of infamy," and the main targets of his dunces" attacks, or the poem's "hall of fame"). Dot graphs are hierarchical, or layered drawings of directed graphs (i.e., graphs in which all the edges are directed from one node to another); this is the default tool to use if edges have directionality, such as in dependency trees (in our case, they highlight Dennis's relationships with characters who are not connected with each other in his social network).

${ }^{9}$ For an explanation of this surprising relation of similarity and an assessment of Haywood's role in the poem, see Ileana Baird, "The Strength of Weak Ties: Eliza Haywood's Social Network in The Dunciad in Four Books (1743)," ABO: Interactive Journal of Women in the Arts, 1640-1830 9, no. 2 (2019): 1-36, https://doi.org/10.5038/2157-7129.9.2.1202

${ }^{10}$ These four categories describe in a more nuanced way than in prior critical assessments the nature of the relationships in which Pope's characters are involved. While the text clearly indicates relations of antagonism or support (character attacked vs. character defended), it also depicts more subtle relations of similarity or dissimilarity that do not necessarily involve a direct attack against, or support for, a particular individual.
} 
character relationships as well (green/similarity, orange/dissimilarity, $\mathrm{red} /$ character attacked, blue/character defended), but it is interactive, indicating, for instance, the number of connections of a particular character when clicking on his or her name.

We have created, thus, social network graphs that make visible what Alex Woloch describes as the "space of the protagonist": ${ }^{11}$ one's network of relations with the other characters in the poem, and the nature of these affiliations. Although it is important to recognize that, just like the maps of large geographical areas, some of these graphs are difficult to read on a computer screen due to the amount of data they represent, they still provide invaluable insights into the argument of the poem. As demonstrated below, this model of social network analysis brings to light data that is structurally embedded in the poem but not obvious or immediately legible given the amount and complexity of information. Our initial goals were (a) to clarify the relationships of these particular dunces with each other and with Pope and his friends, allies, or defenders; (b) to make visible networks of relations that could bring to the surface, in Franco Moretti's words, "hidden patterns" 12 of contacts and exchange, and (c) to assess the magnitude and social ramifications of Pope's attacks. Our final results led, excitingly, to much more than that.

\section{John Dennis in the Poem's Plot Network}

Pope's quarrel with John Dennis, the most important critic of the time, illustrates in an exemplary way the ramifications of the literary feud started by The Dunciad with key personalities of London's cultural life. England's leading critic of the first decade of the eighteenth century, political pamphleteer with strong Whig sympathies, author of moral and religious tracts, and playwright with a constant presence on the English stage, Dennis is one of the most prominent public personalities drawn into the whirlpool of Pope's satire. One of the most vituperative attackers of Pope's

\footnotetext{
${ }^{11}$ Alex Woloch, The One vs. the Many: Minor Characters and the Space of the Protagonist in the Novel (Princeton, NJ: Princeton University Press, 2003).

${ }^{12}$ Franco Moretti, Graphs, Maps, Trees: Abstract Models for a Literary History (New York: Verso, 2005), 54 .
} 
work, becoming, as Samuel Johnson put it, "the perpetual persecutor of all his studies,"13 Dennis is also the perfect victim of Pope's elaborated machinations, which ended up in moral disrepute and severe literary effacement. ${ }^{14}$ None of Pope's dunces - other than Colley Cibber-were subject to a more complicated strategy of ridicule and disparagement in his satire than John Dennis, which is a clear indication of Dennis's prominence in London's cultural life.

A brief account of Dennis's conflict with Pope will help clarify some of the references to the critic in the poem. Their quarrel started in 1711 with Pope's biting (and allegedly unprovoked) remarks in An Essay on Criticism, which ostensibly baffled Dennis:

There well, might Criticks still this Freedom take;

But Appius reddens at each Word you speak,

And stares, Tremendous! With a threatening Eye,

Like some fierce Tyrant in Old Tapestry! $!^{15}$ (1. 584-587)

The reference to Dennis as Appius is inflammatory: it alludes to his failed play, Appius and Virginia (1709), remembered today only because of Dennis's invention of a device that imitated the sound of thunder for use as a stage effect. The causes of Pope's attack are uncertain; as Dennis mentioned in his Remarks upon the Dunciad, he had only met Pope three times before this attack and they never had any disagreements, although the fact that Dennis ignored Pope's Pastorals (1709) might have precipitated the young poet's rancor. ${ }^{16}$ In response, Dennis rushed to publish Reflections, Critical and Satyrical, upon a Late Rhapsody, Call'd, An Essay

${ }^{13}$ Samuel Johnson, "Pope," in The Works of Samuel Johnson, LL.D. (New York: John Dearborn, 1832), 2:236.

${ }^{14}$ Avon Jack Murphy, John Dennis (Boston: Twayne Publishers, 1984), 62.

${ }^{15}$ Alexander Pope, An Essay on Criticism (London: Printed for W. Lewis, 1711), 34.

${ }^{16}$ In Epistle to Dr. Arbuthnot, Being the Prologue to the Satires (1735), Pope seems to point to Dennis's disapproval of his Pastorals: "Soft were my numbers; who could take offence, / While pure description held the place of sense? / Like gentle Fanny's was my flowery theme, / A painted mistress, or a purling stream. / Yet then did Gildon draw his venal quill; / I wished the man a dinner, and sat still. / Yet then did Dennis rave in furious fret; / I never answered I was not in debt" (1. 147-154). Another reason for Pope's attack may be Dennis's insults aimed at William Walsh, Pope's poetic mentor. See Johnson, "Pope," 1: 227. 
upon Criticism (1711), ${ }^{17}$ in which he taunted Pope for his deformity, stating, among other things, that he is "as stupid and as venomous as a hunchback'd Toad," 18 and accusing him of Jacobitism. Pope hit back with The Critical Specimen (1711), where he dubbed Dennis "Rinaldo Furioso, Critick of the Woeful Countenance" (another allusion to one of Dennis's dramatic failures, Rinaldo and Armida), and with The Narrative of Dr. Robert Norris (1713), a veiled defense of Joseph Addison's Cato, which had been virulently attacked by Dennis in the previous year. ${ }^{19}$ In 1715 , the Preface to John Gay's What D'Ye Call It satirized "classical” critics and Dennis's doctrine of poetic justice, a critique in which Dennis thought he discerned Pope's hand. After this attack, Dennis joined Curll in his disparaging campaign against Pope, and published (anonymously) A True Character of Mr. Pope, and His Writings (1716), a venomous pamphlet that described Pope as a "little, but very comprehensive Creature, in whom all Contradictions meet": Pope was "a Beast and a Man," "a Whig and a Tory," "a Rhimester without Judgement or Reason," "a Critick without Common Sense," "a Jesuistical Professor of Truth," "a lurking way-laying Coward, and a Stabber in the Dark," and a "Traytor-Friend," among other qualifications. ${ }^{20}$ Pope struck back in the collectively authored Three Hours after Marriage (1717), where Dennis appeared briefly as "Sir Tremendous Longinus." ${ }^{21}$ Following this bout, Dennis's anti-Pope attacks became more comprehensive: in 1717, he published Remarks upon Mr. Pope's Translation of Homer, in which he criticized Pope's translation of the Iliad for its many "blunders" and "errors," Windsor Forest for "want

${ }^{17}$ John Dennis, Reflections, Critical and Satyrical, upon a Late Rhapsody, Call'd, An Essay upon Criticism (London: Printed for Bernard Lintott, 1711).

${ }^{18}$ Ibid., 26.

${ }^{19}$ Interestingly, Addison denied any involvement in Pope's attack against Dennis, and Dennis confessed that he wrote the attack against Addison at publisher Bernard Lintot's request, who, in turn, had been persuaded by Pope to invite Dennis's contribution.

${ }^{20}$ [John Dennis], A True Character of Mr. Pope, and His Writings. In a Letter to a Friend (London: Printed for S. Popping, 1716). For Dennis's authorship of this piece, see Edward N. Hooker's compelling argument in "Pope and Dennis," English Literary History 7, no. 3 (1940):188-98, https://doi.org/10.2307/2871490

${ }^{21}$ John Gay, Three Hours after Marriage: A Comedy (London printed; reprinted in Dublin by S. Powell, 1717). 
of plan," and The Temple of Fame for being a burlesque imitation of Chaucer's House of Fame. ${ }^{22}$

Their conflict apparently cooled down during the next decade, when Pope subscribed to Dennis's Select Works and his volumes of Letters. In 1727, though, Pope published Peri Bathous, or the Art of Sinking in Poetry, an upside-down Longinian treatise in which Dennis was, again, one of his favorite targets: here, he included the critic among "porpoises," which "put all their Numbers into a great Turmoil and Tempest, but whenever they appear in plain Light ... they are only shapeless and ugly Monsters."23 The 1728 Dunciad contained, again, derogatory references to Dennis, but Pope's most damaging attack against the critic followed the next year, in the much expanded Dunciad Variorum, where Dennis and Giles Jacob were turned into the main protagonists of the poem's sub-textual debate. Dennis retaliated with Remarks on Mr. Pope's Rape of the Lock. With a Preface Occasion'd by the Late Treatise on the Profound, and the Dunciad (1728), a series of seven letters in which he critiqued systematically Pope's composition, characters, machines, sentiments, and style, and whose Preface contained a severe indictment of "Mr. A. P_E"'s literary posterity. ${ }^{24}$ The following year he elaborated on his previous attack in Remarks upon Several Passages in the Preliminaries to the Dunciad ... and upon Several Passages in Pope's Preface to His Translation of Homer's Iliad, a pamphlet dedicated to Lewis Theobald, The Dunciad's first King of Dunces. Pope was described here as a "scandalous Author," showing a "monstrous and impudent Vanity," and as "an empty ... impudent Scribler" whose "Pericranium is ... much out of Order." ${ }^{25}$ As regards The Dunciad itself, Dennis developed here his famous argument about the poem's lack of action and passivity of its hero, provided a harsh

${ }^{22}$ John Dennis, Remarks upon Mr. Pope's Translation of Homer, with Two Letters Concerning Windsor Forest, and the Temple of Fame (London: Printed for E. Curll, 1717).

${ }^{23}$ Peri Bathous, or The Art of Sinking in Poetry, in Miscellanies. The Last Volume (London: Printed for B. Motte, 1727), 27.

${ }^{24}$ John Dennis, Remarks on Mr. Pope's Rape of the Lock. In Several Letters to a Friend. With a Preface Occasion'd by the Late Treatise on the Profound, and the Dunciad (London: Printed for J. Roberts, 1728). Dennis's prediction of Pope's posterity is, indeed, disparaging: "For I will venture to affirm, that Mr. A. P_E has no Admirers among those who have Capacity to discern, to distinguish, and judge; and I will venture to foretell, that Time will make this Affirmation good" (Preface, vi).

${ }^{25}$ Ibid., 5-10. 
comparison between Pope's and Boileau's satirical methods, and elaborated extensively on the motives of his own inclusion in the poem.

What in The Dunciad caused Dennis's vehement response to Pope's satire? It is obvious for anybody looking closely at the poem's plot network-that is, the story told by a character's associations rather than the story told by the poem itself - that much of Dennis's conflict with Pope is included, albeit in a distorted form, in the poem and apparatus. Interestingly, the poem itself is scarce in references to Dennis, who is mentioned in only three brief instances. First, in Book I, 1. 106, Dennis is described as one of the deranged specimens of the "Grub-street race": "She [Dulness] saw slow Philips creep like Tate's poor page, / And all the mighty Mad in Dennis rage." Then, in Book II, Dennis is one of the participants in Dulness's fourth game, the noise competition, which is a hint at his opinionated and highly reactive nature:

'Twas chatt'ring, grinning, mouthing, jabb'ring all, And Noise and Norton, Brangling and Breval, Dennis and Dissonance, and captious Art, And Snip-snap short, and Interruption smart, And Demonstration thin, and Theses thick, And Major, Minor, and Conclusion quick.

Hold (cry'd the Queen) a Cat-call each shall win;

Equal your merits! Equal is your din! (The Dunciad in Four Books, II, I. 237-244)

The lines describe in a brilliant way Dennis's critical method, so often displayed in his attacks against Pope: while Dennis's "demonstration" of The Dunciad's libelous nature, for instance, contains attentive analyses of some of its prefatory material (such as William Cleland's Letter to the Publisher), it constantly fails to provide a serious close reading of the poem itself, thereby undermining its own purpose. Instead, Dennis's prose abounds in "interruptions"-ranging from analyses of classical authors' superiority over Pope to detailed explanations of Pope's false accusations against Dennis-, or in nasty personal attacks against Pope formulated in an often suburban lingo. Dennis's conclusions come, indeed, too "quick" to be accepted at face value, and much of his argument is seriously undermined by the offensive language that permeates throughout. 
Finally, the last reference to Dennis in the main text occurs in Book III, where he is paired as "fool with fool" (1. 176) with Charles Gildon, a minor playwright and critic whom Pope suspected to have written with Dennis the infamous True Character of Mr. Pope and His Writings. Dennis's reaction to this association is, indeed, foolish: in his Remarks on the Dunciad, he dismissed any collaboration with Gildon, admitting implicitly the sole authorship of the libel. ${ }^{26}$ Dennis is thus presented in the poem as an unreliable critic, a lunatic, a libeler, and a fool, in short, as an inconsequential figure with a brief but thunderous presence on the poem's stage.

The details of these qualifications are significantly expanded in footnotes and apparatus, where the critic becomes, surprisingly, the most vocal of Pope's dunces. The story told by the paratext is, indeed, quite different from the story told by the poem: with 92 references in the apparatus (without counting the illustrations, Index of Persons, and Index of Matters), Dennis becomes the uncrowned king of The Dunciad's textual periphery, being placed at the center of a dense network of relations that disclose much of the political and moral motivations of his war with Pope. Dennis is also showcased in three of The Dunciad illustrations, more than any other dunce of the poem (Figs. 8.1 , 8.2, and 8.3). ${ }^{27}$ Again and again, his associations indicate Dennis's pivotal role in some of the most heated debates of the time: Curll's defamatory campaign against Pope, Jeremy Collier's pamphlet war against the "profaneness" of the stage, the arguments about the institution of laureateship, the "Ancients" versus "Moderns" debate, the defense of the classical rules and the sublime in art, the influence of political and social conditions upon the production of letters, the role of religion as a social unifier, and so on.

Dennis's name appears eight times in the List of Abusers alone, which is a clear indication of his central role in dunces' campaign against Pope. Both lists of works attacking Pope published before and after The Dunciad,

\footnotetext{
26 "As to my writing in concert with Mr. Gildon, I declare upon the honour and word of a gentleman, that I never wrote so much as one line in concert with any one man whatsoever." Dennis, Remarks upon the Dunciad, 50; qtd. by Pope in Testimonies.

${ }^{27}$ For more details on the satirical role of The Dunciad illustrations, see Ileana Baird, "Visual Paratexts: The Dunciad Illustrations and the Thistles of Satire," in Book Illustration in the Long Eighteenth Century: Reconfiguring the Visual Periphery of the Text, ed. Christina Ionescu (Newcastle upon Tyne: Cambridge Scholars Publishing, 2011), 329-66.
} 


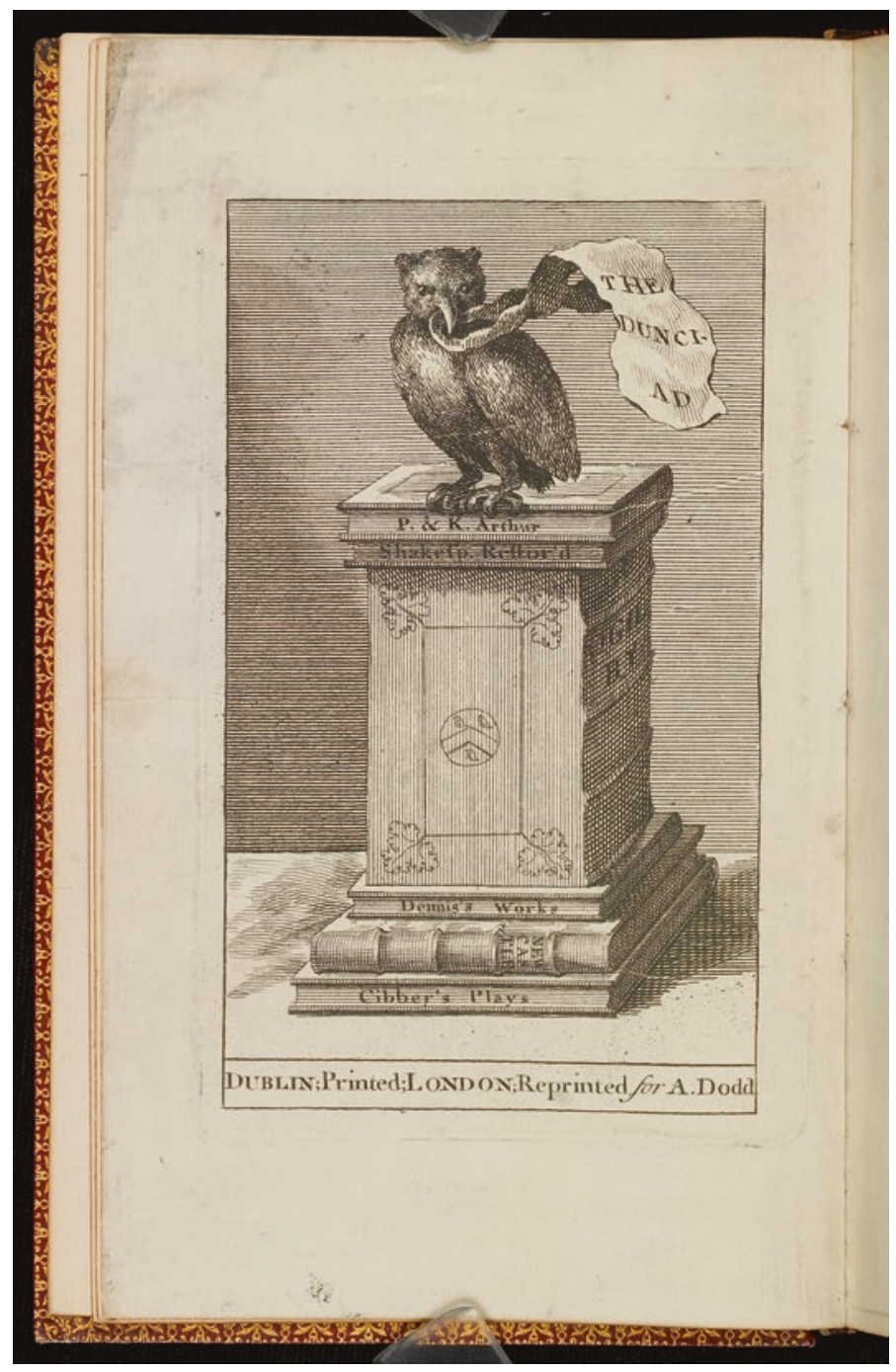

Fig. 8.1 The owl frontispiece to The Dunciad: An Heroic Poem, In Three Books (1728) featuring Dennis's Works. (Courtesy of Albert and Shirley Small Special Collections Library, University of Virginia) 


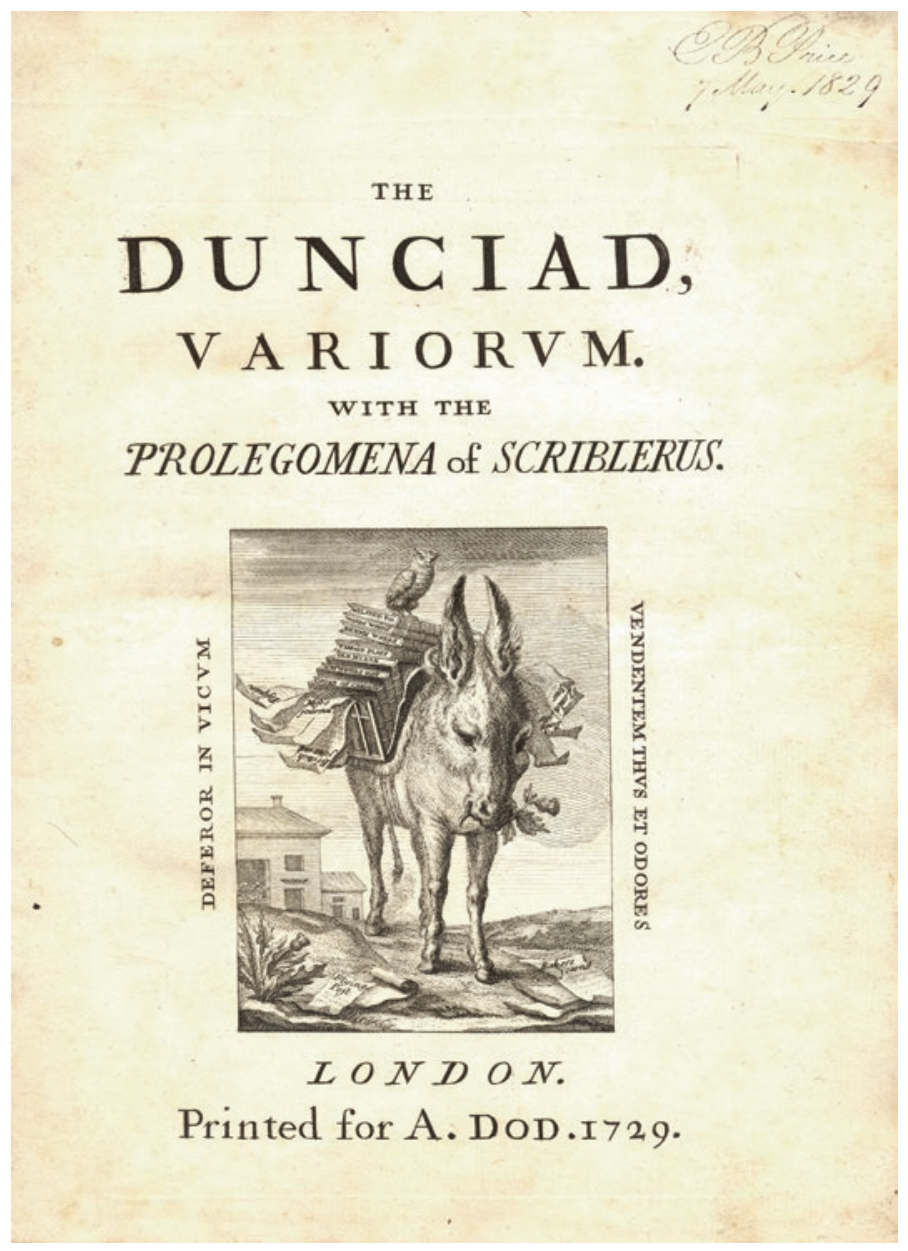

Fig. 8.2 Cover page of The Dunciad, Variorum. With the Prolegomena of Scriblerus (1729), containing the famous image of the ass carrying the dunces' productions. Dennis's Works are showcased here alongside those of Leonard Welsted, Ned Ward, Lewis Theobald, John Oldmixon, and Eliza Haywood. (Courtesy of Professor David Vander Meulen, University of Virginia) 


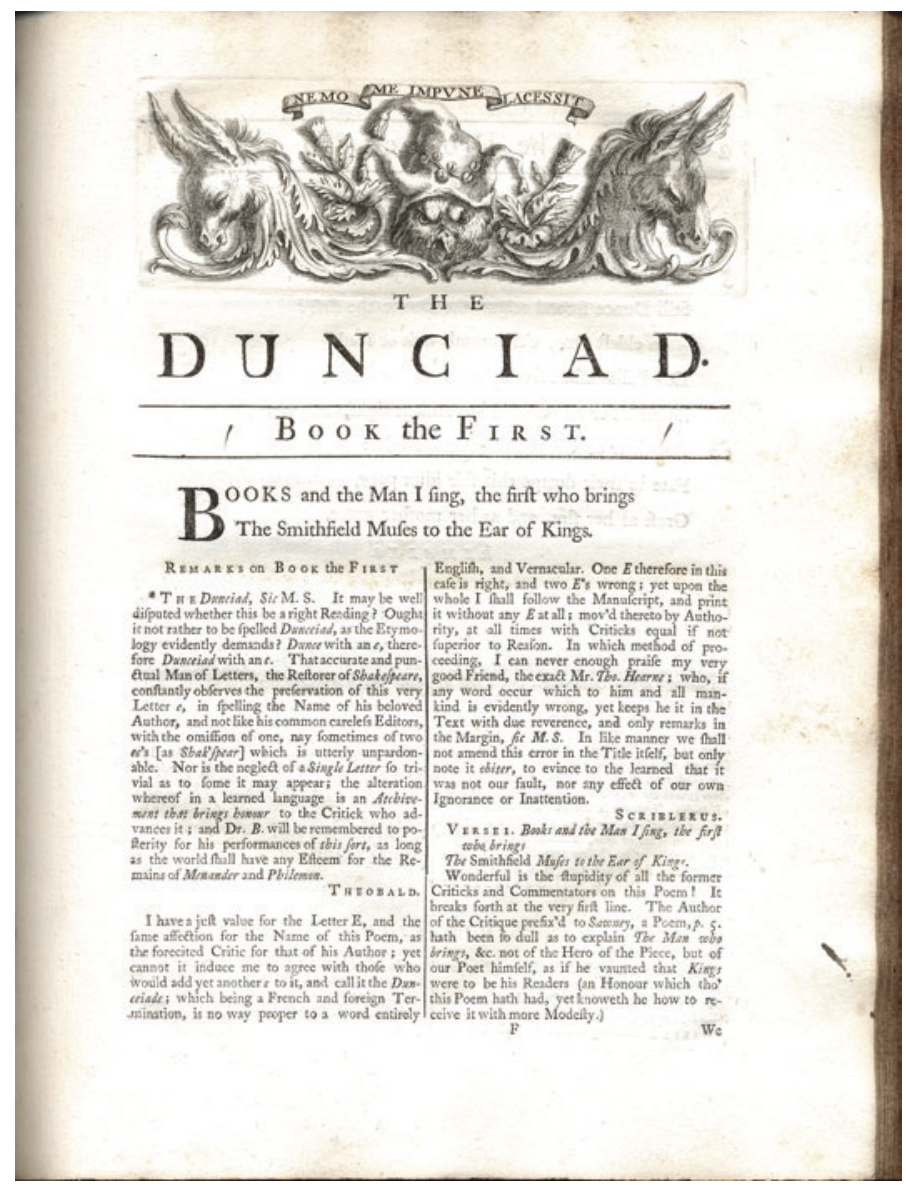

Fig. 8.3 First page of The Dunciad, Variorum. With the Prolegomena of Scriblerus (1729), containing a frontispiece showing an owl wearing a fool's cap, a possible impersonation of critic John Dennis, aka "Furius." (Courtesy of Professor David Vander Meulen, University of Virginia) 
for instance, open with pamphlets by Dennis (Reflections on Essay on Criticism and An Essay on the Dunciad, respectively). This highlights his severe reaction to writings containing personal offense, an attitude considered by Pope unsuitable for a critic and used to his own advantage every time he launched a new offensive against his dunce. Theobald's branding of Dennis as "Furius" in the Censor of 5 January 1717 describes the critic perfectly: in Appendix VIII alone (A Parallel of the Characters of Mr. Dryden and Mr. Pope), Dennis's artillery aims at Pope no less than seventeen times, accusing him of being "a mortal enemy to his country," "a popish rhymester," "an incompetent translator," an ape, an ass, a frog, a coward, a knave, a fool, and "a little abject thing." In addition, the notes to the poem abound in Dennis's remarks on Pope's physical deformity, (lack of) education, his "depravity of genius and taste," 28 his want of genius or admirers, and his substandard knowledge of English and Greek. Thus, Dennis's omnipresence in the footnotes to The Dunciad and in the apparatus construct the poem's paratext as a space ruled by the furious madness of incompetent critics.

\section{John Dennis's Social Network}

Despite general agreement on Dennis's role in "establishing the profession of criticism in England," 29 recent assessments of his legacy have focused disproportionately on his place in The Dunciad and the motivations of Pope's attack against him. ${ }^{30}$ This led critics like John Morillo, for instance, to conclude that "[1]ike all of the other hapless writers entombed

\footnotetext{
${ }^{28}$ Pope, "Testimonies of Authors," Dunciad in Four Books, 65.

${ }^{29}$ Paul D. Cannan, "John Dennis," The Encyclopedia of British Literature 1660-1789, ed. Gary Day and Jack Lynch (Oxford: Oxford University Press, 2015), 1: 407.

${ }^{30}$ See, for instance, John Morillo, "John Dennis: Enthusiastic Passions, Cultural Memory, and Literary Theory," Eighteenth-Century Studies 34, no. I (2000): 21-41, https://doi. org/10.1353/ecs.2000.0063; Kathrine Cuccuru, “That 'Tremendous' Mr. Dennis: The Sublime, Common Sense, and Criticism," in Passions, Sympathy, and Print Culture: Public Opinion and Emotional Authenticity in Eighteenth-Century Britain, ed. Heather Kerr, David Lemmings, and Robert Phiddian (London: Palgrave Macmillan, 2016), 105-21; and, more recently, Philip Smallwood, "Petty Caviller or 'Formidable Assaillant'? Johnson Reads Dennis," The Cambridge Quarterly 46, no. 4 (2017): 305-24, https://doi.org/10.1093/ camqtly/bfx025
} 
in the Dunciad, Dennis has survived primarily as the butt of Pope and his fellow Scriblerians' jokes or, at best, as a minor figure requiring the stronger ally of a canonized author to gain entrance into modern criticism." 31 As I will try to suggest, however, this view goes against Pope's own assessment of the critic's role in the cultural landscape of his time. While acknowledging that Dennis figures "a great deal" in Pope's mock epic, "especially in its sarcastic footnotes," 32 current criticism has failed to recognize his position as a main protagonist of Pope's satire, nor has it addressed the significance of his unequal presence in the poem and the apparatus. Therefore, in the following analysis I will change focus from the history of his conflict with Pope to the way in which the poet constructs Dennis in the poem through his character associations. This change in perspective will allow for a more attentive investigation of the critic's role in the poem and, implicitly, of Pope's perception of Dennis's sphere of influence outside the poem during the genesis of his mock-epic.

Dennis's social network, as extracted from Pope's satire, includes many of the characters involved in the anti-Pope campaign mentioned above. As such, the visualizations we have created provide, first and foremost, camp visibility: they immediately clarify who the characters that Dennis supported or attacked are, which allows for interesting inferences regarding the motivations of these associations. Dennis supports, or is described as being similar to, characters like Eliza Haywood, Thomas Cooke, Leonard Welsted, Bernard Lintot, Edmund Curll, or Elkanah Settle, to name just a few, and attacks characters like John Dryden, Jeremy Collier, Pope, Gay, William Law, Abel Boyer, and Arthur Bedford (Figs. 8.4 and 8.5). These camps indicate obvious hierarchies of value, but they also open up interesting interpretive avenues when looked at in close detail. While the motivations of Dennis's animosity against Pope are well-known, his reasons for attacking authors like Law, Boyer, or Bedford are not immediately clear. They may have clashed, as the notes to the poem suggest, in the debate

\footnotetext{
${ }^{31}$ Morillo, “John Dennis," 21.

32 "John Dennis," Encyclopedia Britannica, 2 January 2020, https://www.britannica. com/biography/John-Dennis
} 


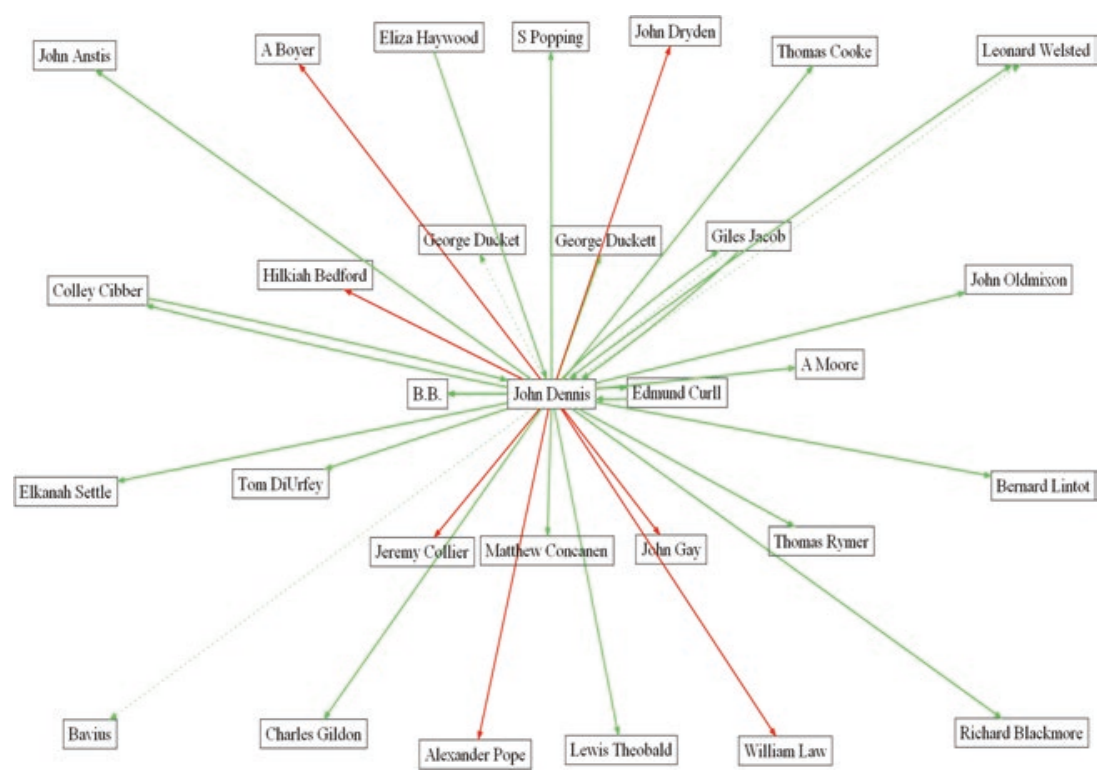

Fig. 8.4 Graph describing John Dennis's relations in poem and apparatus as NEATO (spring-model layout). The relations described indicate similarity (green), characters attacked (red), and characters defended (dotted green). Dennis's relations with Edmund Curll, Giles Jacob, and Leonard Welsted are bidirectional, which indicates strong ties

over the morality of the stage or, given their job description, over religious or political issues. ${ }^{33}$

Two of Dennis's connections are particularly interesting as they describe the critic as being at the center of literary coteries involving notorious

${ }^{33}$ William Law is author of The Absolute Unlawfulness of the Stage-Entertainments Fully Demonstrated (London: Printed for W. and J. Innys, 1726). Dennis attacked him because he thought, in disregard of the actual publication date of his work, that his pamphlet was precisely timed to coincide with the Jacobite attempts at a restoration of the Old Pretender (James Francis Edward Stuart). Arthur Bedford is a vicar who wrote pamphlets against the stage; he was confused by Dennis with Hilkiah Bedford, the alleged author of The Hereditary Right of the Crown of England Asserted (London: Printed for Richard Smith, 1713), and therefore attacked for his support for the Pretender. 
Fig. 8.5 All relations

for John Dennis as DOT

(hierarchical layout).

The graph highlights

Dennis's strong

connection with Colley

Cibber, Edmund Curll, and Giles Jacob (the edges are bidirectional)

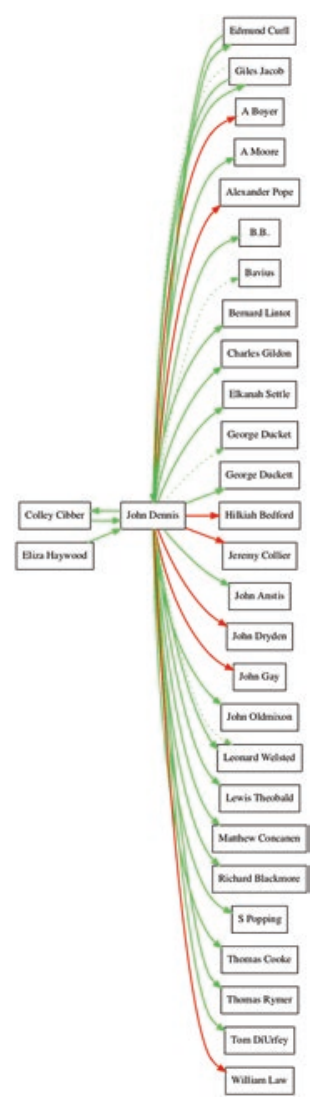

authors or journalists of the time. Dennis's connection with Lewis Theobald, James Moore Smythe, Matthew Concanen, and Thomas Cooke, for instance, a relationship that is not immediately obvious just by perusing the poem, is made visible by these graphs. At further examination, we find that they all belonged to a "Club" of authors who, much like the Scriblerians, used to hold weekly meetings during which they produced offensive pamphlets against their rivals (Appendix II, "List of Abusers"). One of these attacks, a letter against Pope signed by W. A. (probably William Arnall) and published in the Mist's Weekly Journal on June 8, 
1728, is directly referenced in The Dunciad. Given that the Mist's Journal published several anonymous attacks against Pope, we may assume that some of them had been contributed by members of Dennis's "Club." ${ }_{4}$

The second reference to Dennis's cultural leadership appears in Appendix VI, "Of the Poet Laureate," where he is described as "the worthy president" of the Grub Street Journal "society" of authors. This affiliation seems to point to a category of authors belonging to a specific locale rather than to authors who had their works published in the journal. ${ }^{35}$ Indeed, in A Tale of a Tub (1704), Swift makes numerous references to the "Society" of Grub Street, or "the Grub-street Brotherhood," which is described as a "spatious Commonwealth of writers" strategically located in the immediate vicinity of the "Bedlam" mental hospital. ${ }^{36}$ Thus, describing Dennis as presiding over the large category of "hack" writers and as leading the "Club" of anti-Pope authors publishing in The Mist's Weekly Journal indicates Pope's acknowledgement of his central cultural role in the real space of the city. This explains Pope's deliberate choice to give Dennis a main role in his mock-epic, a role not immediately obvious when reading the poem without paying close attention to its notes.

Another important connection revealed by these graphs is that between Dennis and Giles Jacob, an obscure character mentioned in only one instance in the poem (III, 1. 149-150), which raises legitimate questions about the reasons for this association. Mainly known as a legal writer, Jacob is also the author of The Poetical Register, a literary history of

\footnotetext{
${ }^{34}$ Given that the majority of these attacks were published under pseudonym, their authorship is difficult to establish. It is true, however, that a concerted attack against Pope was hosted in the pages of the Mist's Weekly Journal, which published several malicious pieces against the poet. See, for instance, Letter XXIII, Homer's Character Attempted in Blank Verse, Letter XXVII, BS's Scurrilous Reflections upon Mr. Pope, and Letter LVII, The Great Mischief Accrued to Church and State from the Assaults of Illiterate Pamphleteers, republished in A Collection of Miscellany Letters, Selected out of Mist's Weekly Journal, vol. 2 (London: Printed by N. Mist, 1732). The Mist's Journal also appears on the cover of the Dunciad Variorum (1729), together with other pro-governmental publications, such as The London Journal, The Daily Journal, The British Journal, Pasquin, and The Flying Post.

${ }^{35}$ The Grub Street Journal (1730-1737) was a publication that satirized popular journalism and hack writing that was believed to have been started by Pope himself. However, although he did sporadically contribute to the journal, Pope was not the initiator of this venture but the clergyman Richard Russel and botanist John Martyn.

${ }^{36}$ Jonathan Swift, A Tale of a Tub. Written for the Universal Improvement of Mankind. To Which Is Added, an Account of the Battel between the Antient and Modern Books in St. James Library (London: Printed for John Nutt, 1704), 41-43.
} 
contemporary writers that had caused Pope much angst due to accusations of being the "Trumpeter" of his own praise. ${ }^{37}$ Within Dennis's social network, the relationship with Jacob is an outlier; that is, it stands out as atypical given the high frequency with which the two are associated. As seen in Figs. 8.4 and 8.6, the association between the two is one of similarity and support: Jacob wrote a letter to Dennis in which he disparaged Pope, a letter which Dennis published in his Remarks to the Dunciad and, subsequently, Dennis defended Jacob against Pope. A close analysis of these graphs also shows the strength of their relationship: the tie is bidirectional (the two characters interact with and support each other), and it occurs more than once (Fig. 8.6). Indeed, as revealed by this graph, Dennis and Jacob are the most vocal critics of the first three books of The Dunciad, being mentioned 92 and 25 times, respectively, in the apparatus. Together with Dennis, Jacob plays the role of the indiscriminate critic, being constantly quoted in relation to authors considered by Pope of little consequence: Laurence Eusden, Ned Ward, Lewis Theobald, John Ozell, Eustace Budgell, John Oldmixon, and Susannah Centlivre. In other words, the most important critic of the first half of the century is associated with a would-be critic in the poems' textual underground in an effort to diminish Dennis's inflated persona as a cultural guardian and suggest their similar ineptitude.

\footnotetext{
${ }^{37}$ Giles Jacob, The Poetical Register: Or, The Lives and Characters of All the English Dramatick Poets. With an Account of Their Writings, 2 vols. (London: Printed by E. Curll, 1719-1720). Although he wrote favorably about Pope, whom he praised for his "great Ease" and "Strength of his Compositions," Jacob criticized here Three Hours after Marriage (1717), a comedy authored by "three mighty Bards" (John Gay, Pope, and Arbuthnot), for containing "some extraordinary scenes ... which ... trespass on Female Modesty" (1:115). Even worse, Jacob praised The Confederates (1717), a production of the phantom poet Joseph Gay (aka John Breval), an author hired by Curll to attack Pope and his allies. Consequently, Pope included Giles Jacob in the 1729 edition of The Dunciad to punish him for his attacks against his friend, John Gay, and Scriblerians at large. Jacob immediately allied himself with John Dennis, who included Jacob's letter attacking Pope in his notorious Remarks upon the Dunciad (1729); here, Jacob revealed "the true secret History" of the "selfish Mr. Pope," who had written the "high Praises and Commendations" contained in The Poetical Register himself. Jacob is also the author of The Rape of the Smock: An HeroiComical Poem (London: Printed for R. Burleigh, 1717), a rewriting in scatological register of Pope's masterpiece, The Rape of the Lock. Jacob's poem was republished or anthologized frequently at the time, together with writings by Pope.
} 


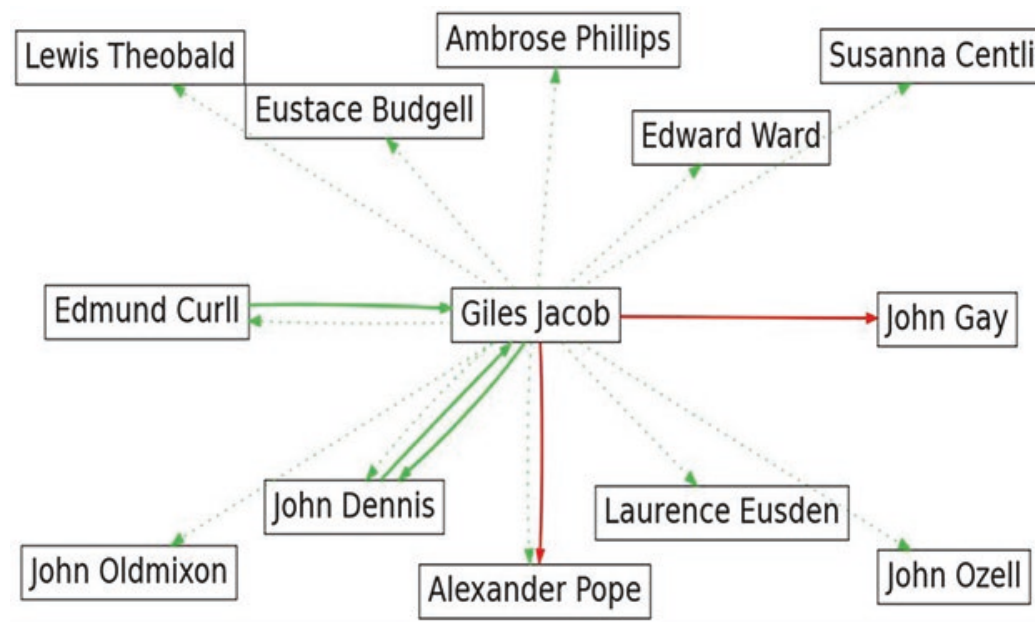

Fig. 8.6 All relations for Giles Jacob as NEATO (spring-model layout). This graph highlights Jacob's close relationship with critic John Dennis, with whom he is in a relation of similarity, and with Edmund Curll, whom Jacob supported in his campaign against Pope

Another interesting observation involving Dennis and Jacob sheds light on Pope's strategy of revising the poem after the change of kings and addition of a fourth book in 1742. When tabulating Dennis's and Jacob's connections, I realized that the two were not mentioned even once in the footnotes to the fourth book of The Dunciad. As we know, The Dunciad in Four Books is a significant revision of the previous text that replaces playwright Lewis Theobald with actor and Poet Laureate Colley Cibber as King of Dunces. In light of this major change, Pope made substantial revisions to the poem's argument to accommodate the new hero. Dennis's and Jacob's places are consequently taken in Book IV by Richard Bentley, "the era's most formidable annotator," 38 and Martinus Scriblerus, a fictional alter ego of Bentley's; in other words, a pedant (Bentley) replaces a mad critic (Dennis), and a fictional character (Scriblerus) replaces an amatory critic (Jacob). This suggests a new pairing of Dennis and Bentley over

${ }^{38}$ Zerby, The Devil's Details, 54-55. 
their shared acribia and of Jacob and Scriblerus over their similar lack of authority in the literary field. These associations may indicate that Pope targeted these dunces not only because of personal bouts against the poet but also because of reasons that were more comprehensive in nature and involved both their moral and cultural incompetence.

The most revelatory finding of this analysis is Dennis's prominent role in the social network of The Dunciad. Although Dennis is mentioned in the poem itself in only three brief instances, he is one of the best-connected characters in the text as a whole, being in a relationship of support, similarity, or antagonism with no less than 29 other protagonists. Using Malcolm Gladwell's suggestive term, I have described such an individual as a "connector," that is, a protagonist who has a high number of ties with other characters. ${ }^{39}$ Connectors are important not only because of their ability to bring together a large number of individuals from different walks of life but also because, by doing so, they have the capacity to spread rumors and gossip, disseminate innovation, and start cultural trends. As Mark Granovetter pointed out, their central position within a network gives the information spread by group members the needed authority. ${ }^{40}$ Indeed, as shown by these graphs, Dennis is one of the three connectors of the poem, together with Colley Cibber, the last King of Dunces, and with publisher Edmund Curll (Figs. 8.7 and 8.8). The Shiva graph, in particular, is very useful in highlighting the poem's three connectors and the spread of their influence along their respective networks: as made obvious by this graph, each dunce can reach another dunce through his or her acquaintances in two to five steps, ${ }^{41}$ and a connector in only one to two steps. We may hypothesize, therefore, that Dennis's position as one of the poem's connectors is granted by his acting as a liaison between various characters belonging to the cultural, political, and religious spheres of the time. ${ }^{42}$ Thus, the Shiva graph illustrates beautifully the relatedness and

\footnotetext{
${ }^{39}$ Malcolm Gladwell, The Tipping Point. How Little Things Can Make a Big Difference (New York: Back Bay Books, 2000), esp. 30-59.

${ }^{40}$ Mark S. Granovetter, “The Strength of Weak Ties," The American Journal of Sociology 78, no. 6 (1973): 1360-80, http://www.jstor.org/stable/2776392

${ }^{41}$ Stanley Milgram, “The Small World Problem,” Psychology Today 1, no. 1 (1967): 65.

${ }^{42}$ As Gladwell explains, connectors are "people with a special gift for bringing the world together" because of their ability "to occupy many different worlds and subcultures and niches" and effectively navigate among them. See Gladwell, The Tipping Point, 38 and 48, respectively. A similar argument was made later on by Barabási, who pointed out that "the
} 


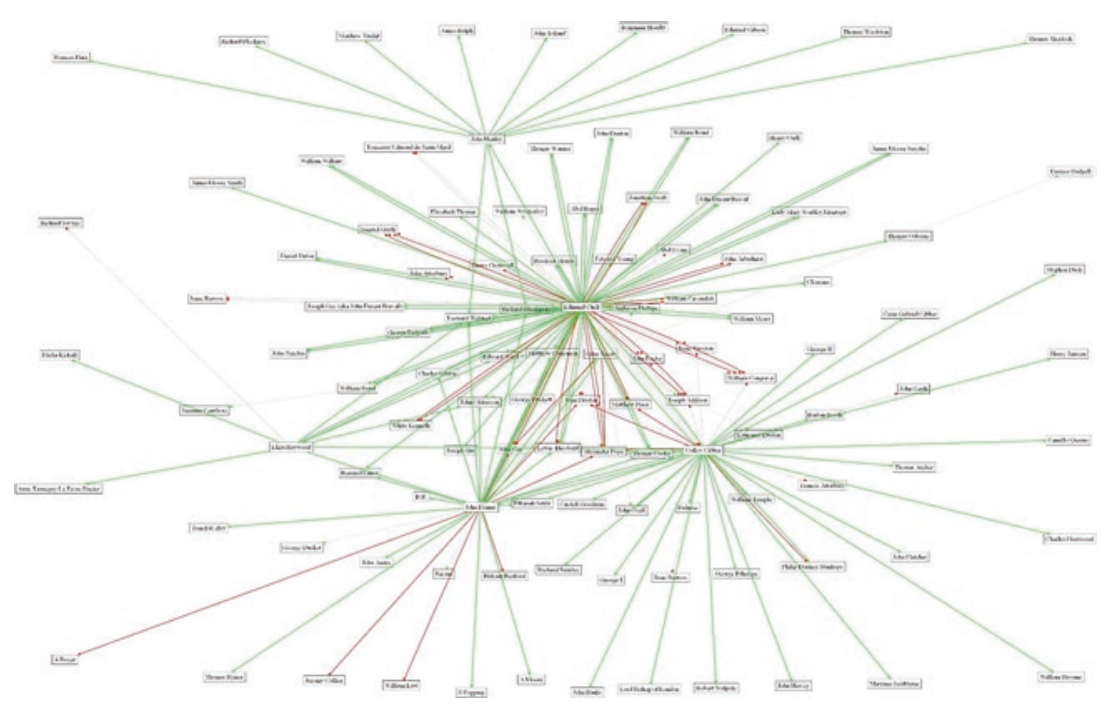

Fig. 8.7 Graph showing the social networks of all the six dunces considered as NEATO (spring-model layout). This graph highlights the three connectors of the poem: John Dennis, Edmund Curll, and Colley Cibber

multiplicity of spaces - social, political, cultural — that describe eighteenthcentury London, spaces which "attain 'real' existence by virtue of networks and pathways, by virtue of bunches or clusters of relationships."43

These graphs also make evident the nature of Dennis's connections and thus the role played by the critic in the cultural space of eighteenth-century London. For instance, Dennis has strong, bidirectional ties (i.e., ties with individuals in his close circle of friends or that involve "reciprocal services" ${ }^{44}$ ) not only with Giles Jacob but also, importantly, with the other two connectors of the poem, Colley Cibber and Edmund Curll. Dennis's connections with Cibber are especially interesting given the 1742 revision

truly central position in networks is reserved for those nodes that are simultaneously part of many large clusters" due to their ability to be at home in various spheres, from arts to sciences. See Albert-László Barabási, Linked: How Everything Is Connected to Everything Else and What It Means for Business, Science, and Everyday Life (New York: Basic Books, 2014), 61.

${ }^{43}$ Henry Lefebvre, The Production of Space, trans. Donald Nicholson-Smith (Oxford: Blackwell Publishers, 1995), 86.

${ }^{44}$ Granovetter, "The Strength of Weak Ties," 1361. 


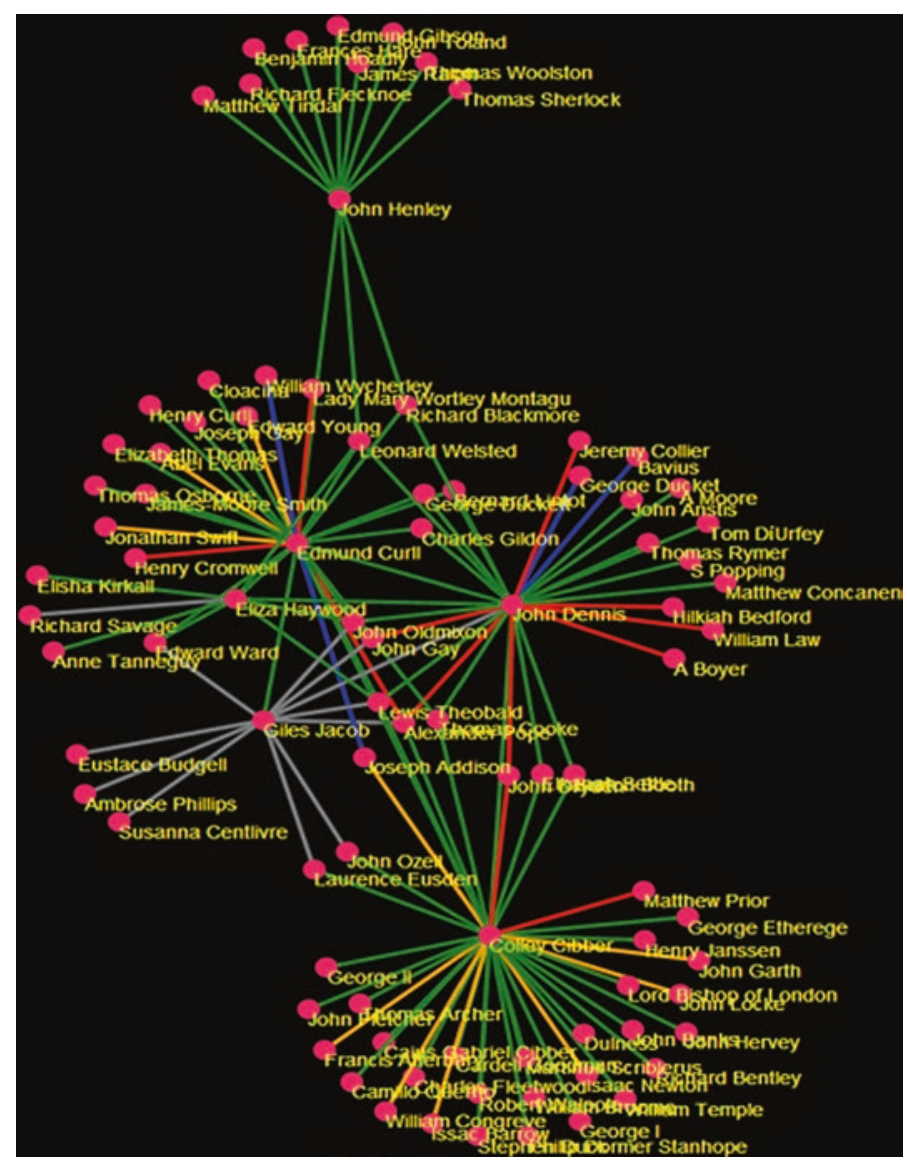

Fig. 8.8 Shiva Graph. This graph gives the viewer a keen sense of the relatedness of all the characters in the poem and makes visible the poems' three connectors: Colley Cibber, Edmund Curll, and John Dennis

of the poem, which involved a change of kings: the critic is mentioned twice in relation to Cibber, once in a context suggesting their similar blindness to personal satire ("Testimonies") and once in a context suggesting their sycophancy toward the ruling class (Appendix VI, "Of the Poet Laureate"). Dennis's relations with Curll, on the other hand, highlight their similar animosity toward the poet (they both are authors "whose 
wrath is perilous"45), cowardice (they both feared Pope's "slander and poison" 46 ), and malicious spread of false rumors (they both wrote about Pope's "profaneness and immorality"). ${ }^{47}$ These positionings are important not only because they give the examiner a new way of looking at the argument of the poem by identifying the main protagonists involved in articulating this argument but also because they highlight actors with similar roles, or actors who are "regularly equivalent" within the network due to having similar patterns of relationships. ${ }^{48}$ Conversely, Dennis has weak ties (i.e., occasional ties with individuals who are remote acquaintances, or, in our case, peripheral within the poem's social network) with authors like George Duckett, S. Popping, and Thomas Rhymer, to give just a few examples. Although these characters are connected with Dennis, they are not directly connected with any other members of his network; however, they all belong to the same camp and/or support the same connector. ${ }^{49}$ The importance of these weak ties should not be underestimated: the connections with people who are not members of one's close group of friends are important because they provide a bridge, that is, "the only route along which information or influence can flow" ${ }^{50}$ from one group to another. In other words, the weak ties in a network expand the radius of the connections within the network and, by doing so, they are best placed to diffuse innovation and spread opinion. Indeed, when looking closely at Dennis's connections, they reflect the critic's involvement in some of the most heated debates of the epoch: Curll's defamatory campaign against Pope, Jeremy Collier's pamphlet war against the "profaneness" of the stage, the argument about the institution of laureateship, the "Ancients" versus "Moderns" debate, the defense of classical rules and the sublime in art, the influence of political conditions upon the production of letters, the role of religion as a social unifier, and so on (Table 8.1).

${ }^{45}$ Pope, Dunciad in Four Books, 60.

${ }^{46}$ Ibid., 113.

${ }^{47}$ Ibid., 188-89.

${ }^{48}$ As explained by Hanneman and Riddle, "actors that are regularly equivalent do not necessarily fall in the same network positions or locations with respect to other individual actors; rather, they have the same kinds of relationships with some members of other sets of actors." See Robert A. Hanneman and Mark Riddle, "Network Positions and Social Roles: The Idea of Equivalence," in Introduction to Social Network Methods (Riverside, CA: University of California, Riverside, 2005), https://faculty.ucr.edu/ hanneman/nettext/ C12_Equivalence.html

${ }^{49}$ Another interesting area of investigation would be to compare the membership of these three social networks, identify similarities and/or differences, and hypothesize on the power dynamics each of them suggests.

${ }^{50}$ Granovetter, "The Strength of Weak Ties,” 1364. 
Finally, this analysis of Dennis's social network reveals the competing stories told by the poem and the apparatus. As already indicated, Dennis is mentioned in only three brief instances in the poem: in Book I, 1. 106, as "the mighty Mad" for his perpetual "rage" against his opponents, in Book II, 1. 239-42, as an inept critic and a highly reactive individual, and in Book III, 1. 173, where he is associated, "fool with fool," with Charles Gildon, a hack writer with whom he allegedly wrote $A$ True Character of Mr. Pope (1716). These attacks are neither particularly developed nor do they give Dennis a prominent role in the poem's plot network. However, when looking at the poem's apparatus, Dennis is mentioned no less than 92 times in the prefatory material, Testimonies, Notes to Testimonies, List of Abusers, appendices, and footnotes, becoming the uncrowned king of The Dunciad's textual periphery. The story told by the apparatus is in stark contrast with the story told by the poem, involving Dennis in a rich network of relations with a large number of characters of loose morals, little talent, or suspect associations. Pope's method of disparaging Dennis is, thus, deeply subversive: he describes Dennis as doing his work of cultural policing from a textual underground where the value criteria are fundamentally flawed.

The findings resulting from performing this type of analysis are even more interesting when working with larger datasets. As seen in Figs. 8.9 and 8.10, the intersections of the six social networks created during this project have led to revelatory results: these visualizations single out the seventeen dunces (out of many dozens) who are central to the poem's plot network, or the poem's "hall of infamy," and the four authors epitomizing "good writers" (i.e., Alexander Pope, John Gay, Joseph Addison, and John Dryden), or the poem's "hall of fame." Most importantly, these social networks show that Pope's dunces are a cultural category that, far from representing a marginalized, minority, or disempowered group, participates in a forceful way in shaping public opinion. Therefore, unlike Nancy Fraser, who argues for the inclusion of "subaltern" groups in the public sphere, I contend here that Pope's dunces are engaged in discourses that place them in the same realm of public debate with cultural authorities, rather than in a subaltern position. While "counterpublic"51 is a term that suggestively encapsulates the idea of competing interests-be they divided along class, gender, or political lines-, a networked public may better describe the collaborative nature of the public sphere of the time, which I see not as a conglomerate of divergent ideologies, but as an organic whole.

\footnotetext{
${ }^{51}$ Nancy Fraser, "Rethinking the Public Sphere: A Contribution to the Critique of Actually Existing Democracy," Social Text 25/26 (1990): 61, https://doi.org/10.2307/466240
} 


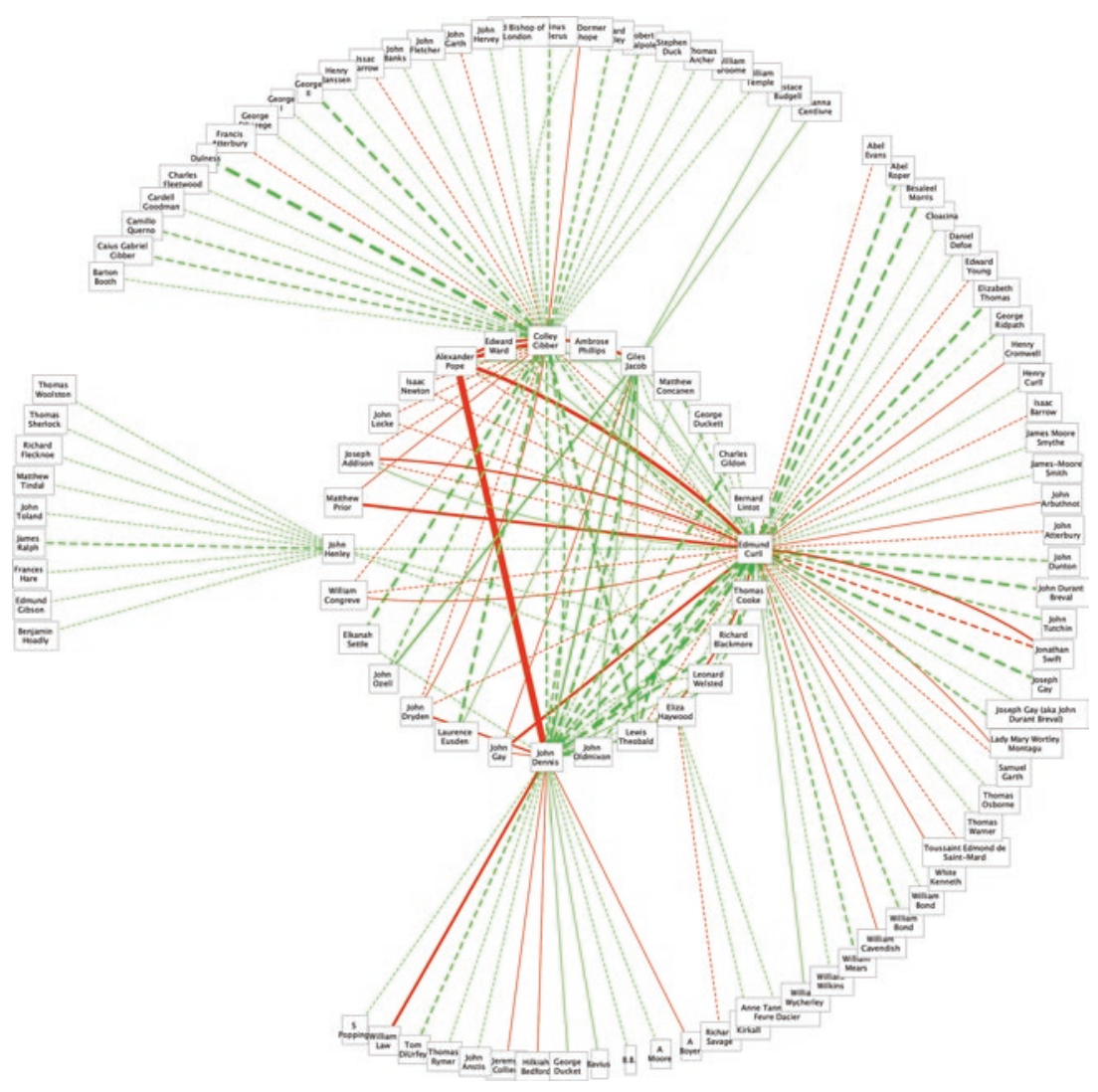

Fig. 8.9 The Inner Circle. Full view of all networks of the six dunces considered as CIRCO (circular layout). This graph highlights the central and the peripheral characters of the poem and apparatus

\section{Conclusion}

Acknowledging Dennis as the uncrowned king of the Dunciad's textual periphery needs to be understood less as Pope's victory cry against his most spiteful attacker and more as an expression of his concern with the critic's role as a cultural and social regulator. As England's leading critic of the first decades of the century, Dennis held a central position in the literary landscape of the time: his contributions to establishing an English canon by reassessing the influence of the "Ancients" on modern thought and emphasizing the importance of rules in art in The Impartial Critick 


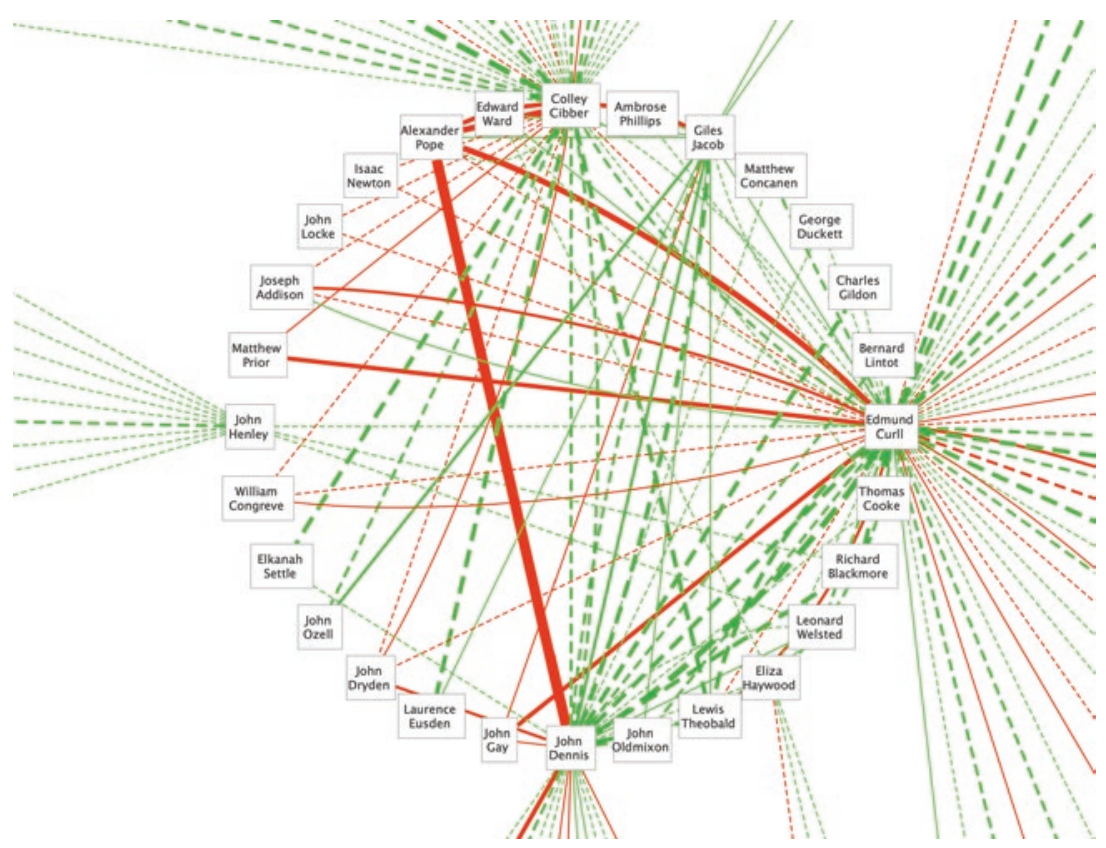

Fig. 8.10 The Inner Circle. Detail view of all networks of the six dunces considered as CIRCO. This detail view highlights characters who appear in more than one network, or the main protagonists of the poem and the apparatus. The hall of fame/"good writers," includes four authors: Alexander Pope, John Gay, Joseph Addison, and John Dryden. The hall of infamy/"bad writers" includes seventeen authors: Colley Cibber, Edmund Curll, Eliza Haywood, John Henley, John Ozell, John Oldmixon, Lewis Theobald, Giles Jacob, Laurence Eusden, Elkanah Settle, Thomas Cooke, John Dennis, Bernard Lintot, Charles Gildon, George Duckett, Leonard Welsted, and Richard Blackmore

(1693), The Advancement and Reformation of Modern Poetry (1701), and The Grounds of Criticism in Poetry (1704) still pass the test of time. Better known today for his theory of enthusiasm and the sublime as "rational" delight, ${ }^{2}$ Dennis is also a precursor of the Romantic movement, having a direct influence on William Wordsworth and Samuel T. Coleridge. More importantly, though, Dennis epitomized for Pope the seminal role played

${ }^{52}$ The Critical Works of John Dennis, ed. Edward Niles Hooker (Baltimore: The Johns Hopkins Press, 1941), 2: 381. 
by a critic in shaping public opinion, acting as a liaison among diverse social spheres. This is reflected both by his oeuvre ${ }^{53}$ and, as this analysis has attempted to demonstrate, by his social network, which highlights the critic's involvement with individuals occupying a variety of political, religious, and cultural spheres. Dennis's, Cibber's, and Curll's roles as the poem's connectors are thus explained by the "multiple components of their identities and engagements within society." 54

This type of social network analysis also answers Martin Paul Eve's important question: "what can the computer see, in its repetitive and unwavering attention to minute detail, that is less (or even invisible to human readers?" 55 As this case study demonstrates, Dennis's social network enhances camp visibility and clarifies the nature of his associations, highlights the critic's central role as one of the three "connectors" of the poem, calls attention to the competing stories told by the poem and the apparatus, identifies in Jacob a network outlier that sheds light on Pope's elaborated defamatory campaign against the critic, and singles out Dennis as the uncrowned king of The Dunciad's textual periphery. Although Dennis's associations are often meant to suggest the critic's blurry sense of cultural value and tempestuous character, by assigning him the main role in the apparatus, Pope implicitly acknowledges Dennis's centrality in the cultural landscape of early eighteenth-century London. Pope's argument against Dennis seems to question, therefore, less his ideas and more his moral competence: a committed Whig with a lifelong service to various political patrons, an individual with a highly volatile temper, and a critic with a tendency "to crack nuts with a sledgehammer," 56 Dennis does not meet the impartiality requirement of his job description.

\footnotetext{
${ }^{53}$ Dennis published extensively on the benefits of the government's regulation of the theater (The Stage Defended, 1726), as well as on other issues of public interest, such as foreign influence on local culture (An Essay on the Operas after the Italian Manner, 1706), or public morality (Vice and Luxury Publick Mischiefs, 1724). He also called attention to the impact of political and social conditions on the production of letters (A Large Account of Taste in Poetry, 1702) and to the importance of religion in "cementing Societies" (The Grounds of Criticism, 1704).

${ }^{54}$ Dan Edelstein and Chloe Summers Edmondson, "Introduction: Historical Network Analysis and Social Groups in the Enlightenment," in Edmondson and Edelstein, Networks of Enlightenment, 11.

${ }^{55}$ Martin Paul Eve, "Close Reading with Computers: Signals, Parts of Speech, and David Mitchell's Cloud Atlas," SubStance 46, no. 3 (2017): 77, http://www.muse.jhu.edu/ article/676240

${ }^{56}$ James R. Sutherland, review of The Critical Works of John Dennis, ed. Edward Niles Hooker, The Review of English Studies 18, no. 69 (January 1942): 118, www.jstor.org/ stable/509884
} 


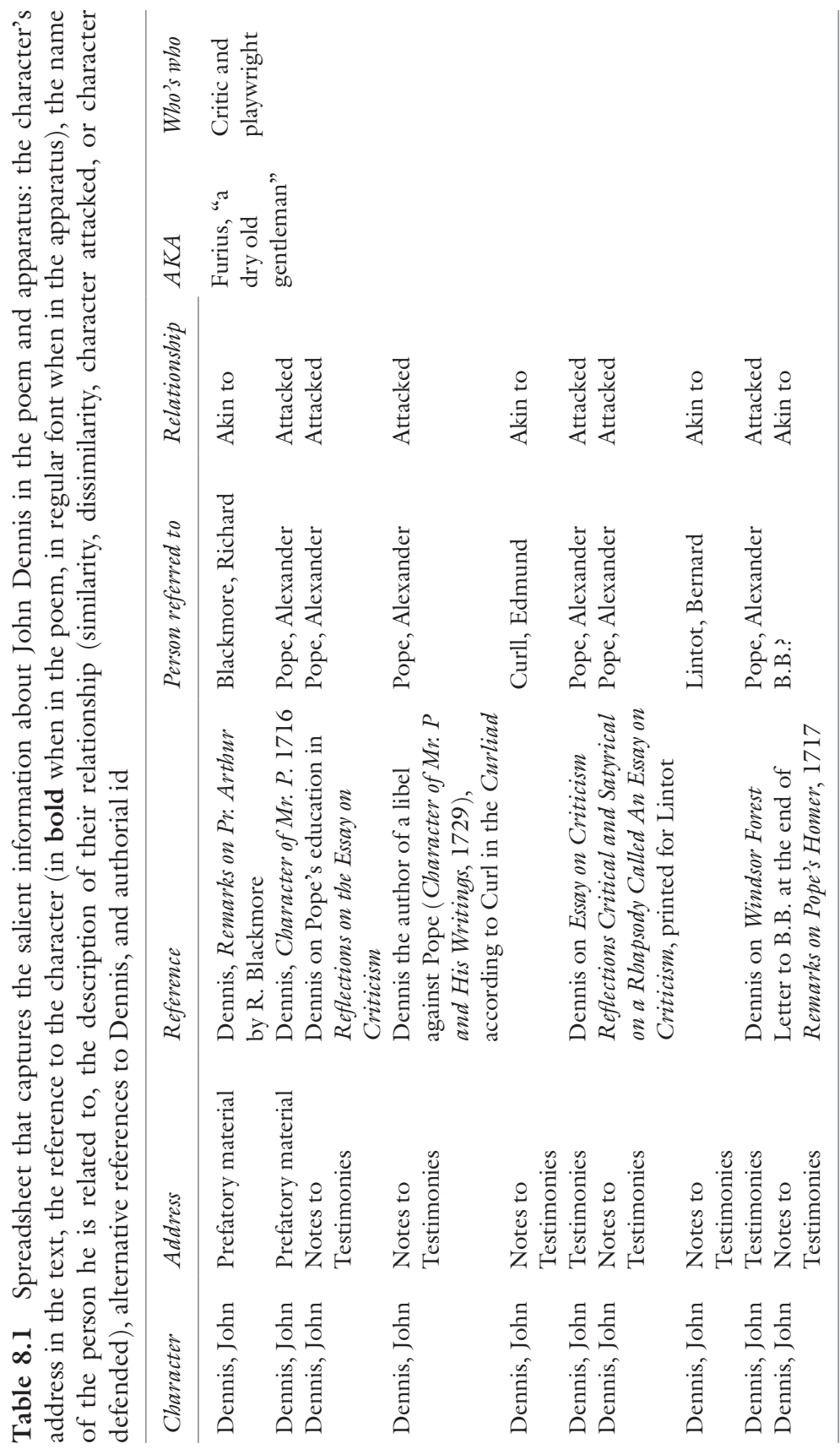




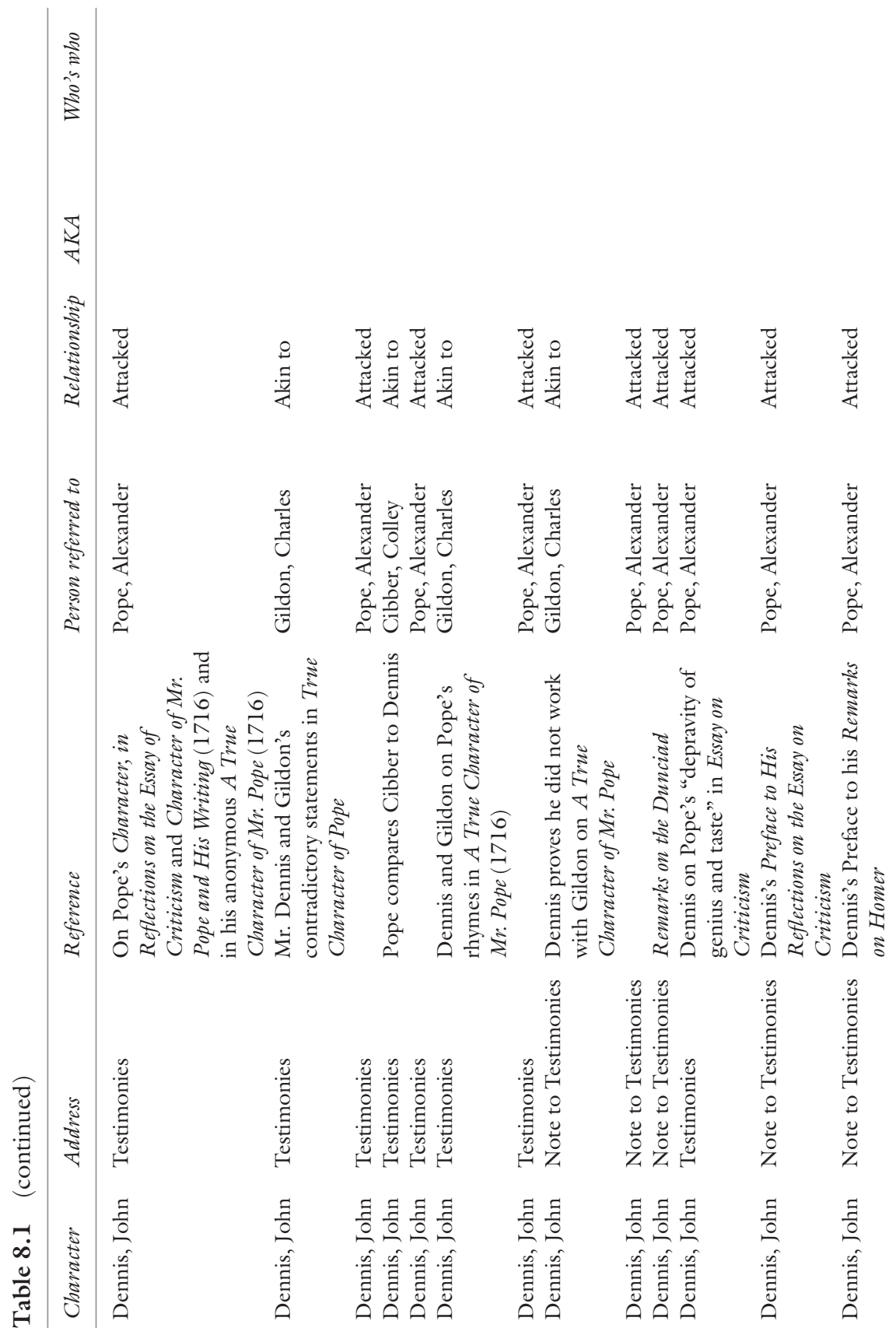




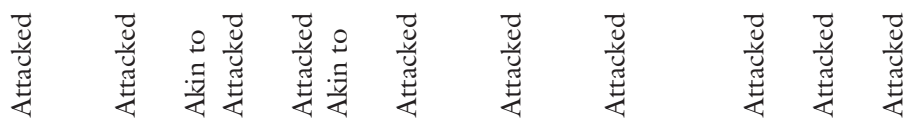

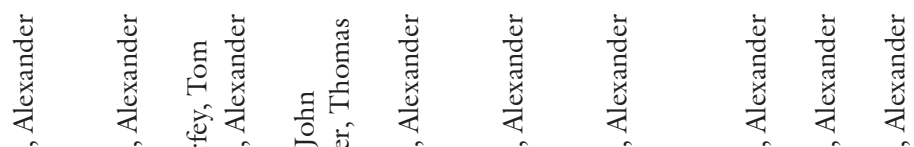

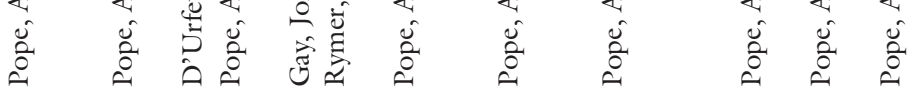

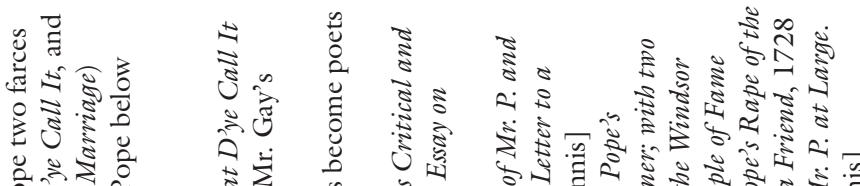

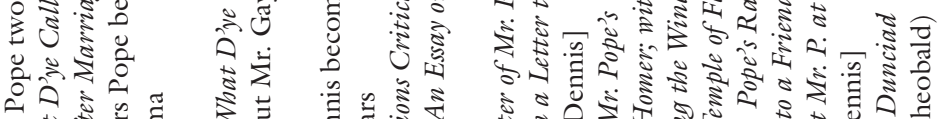

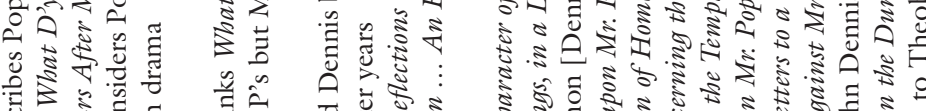

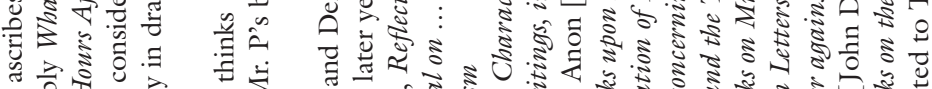

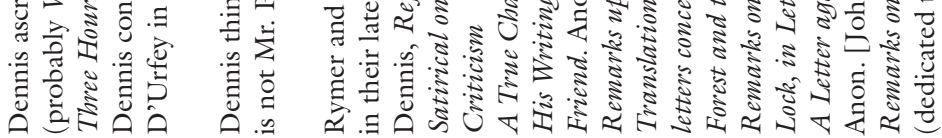

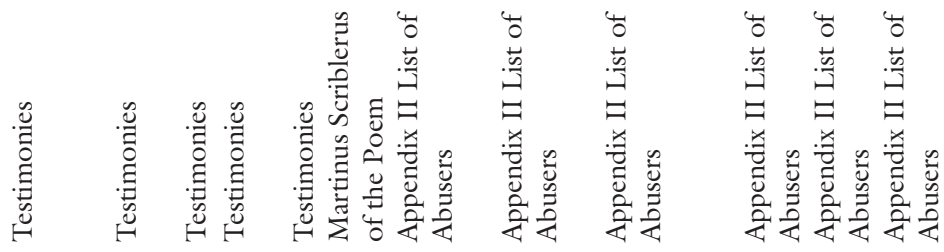

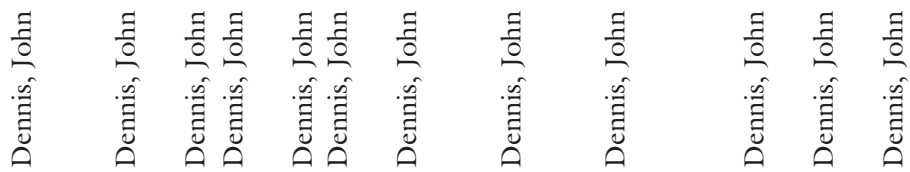




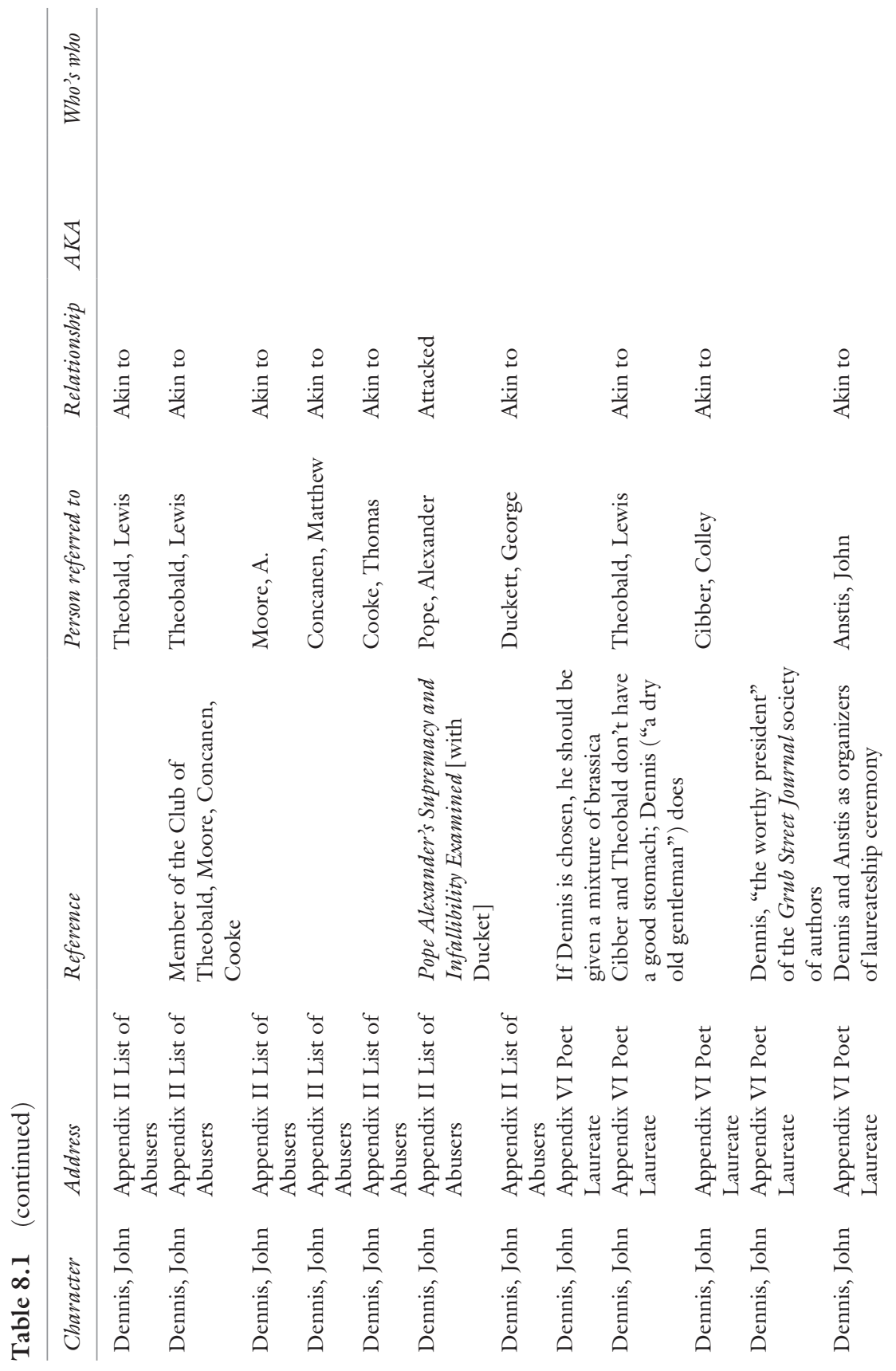




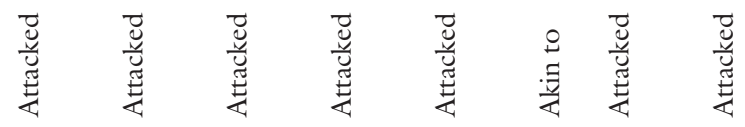

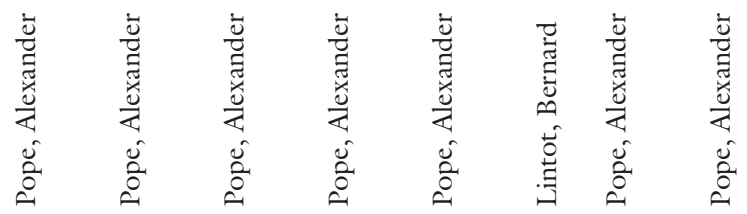

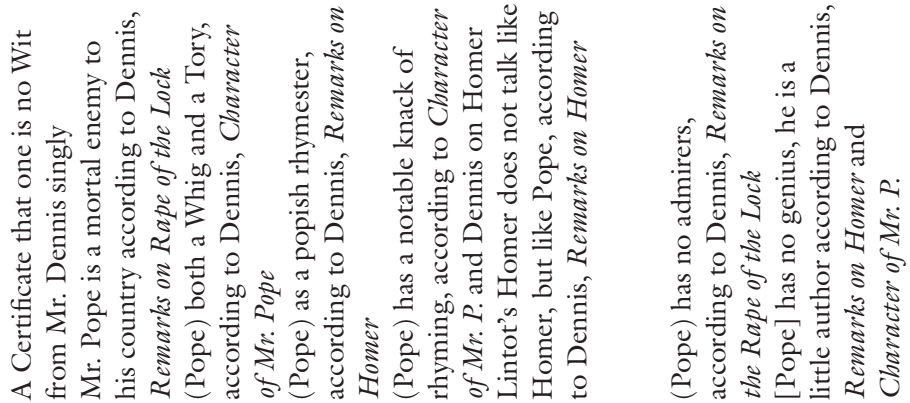

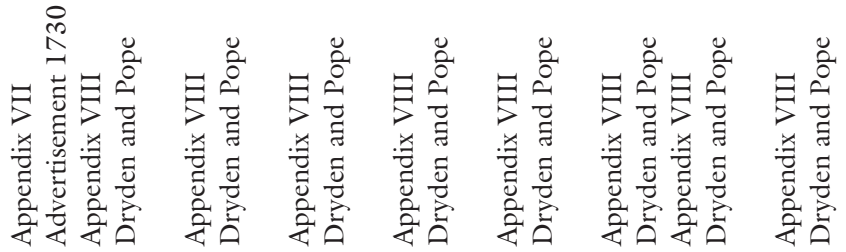

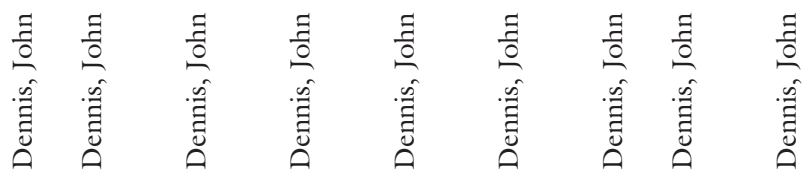




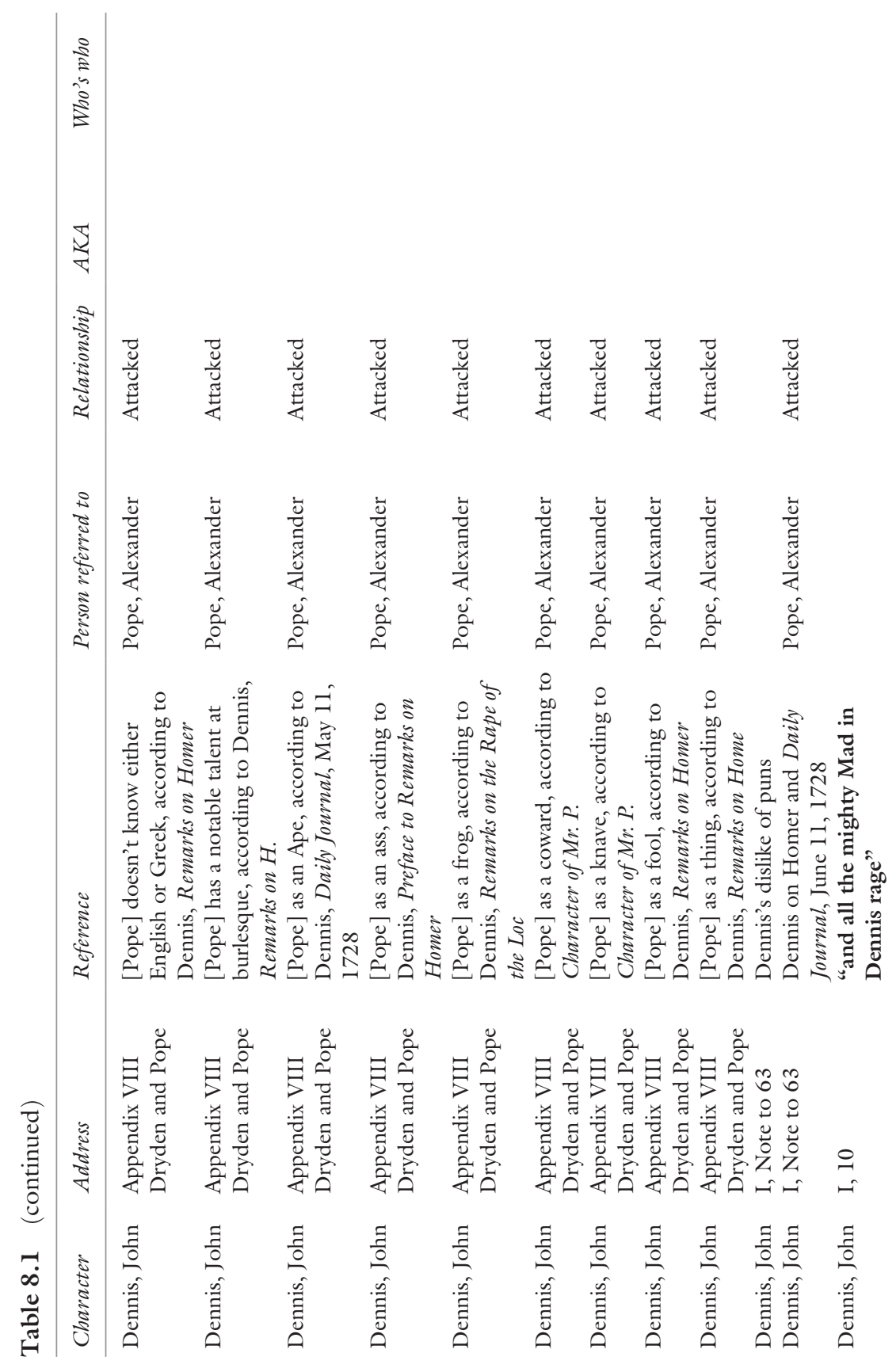




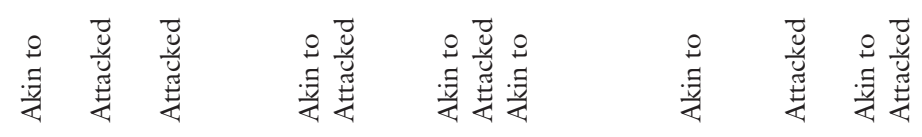

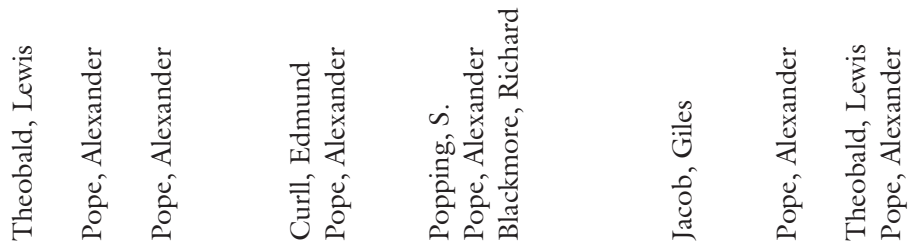

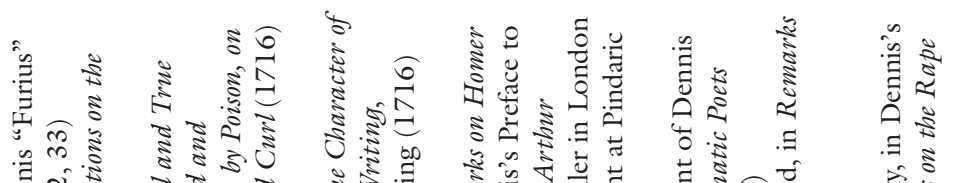

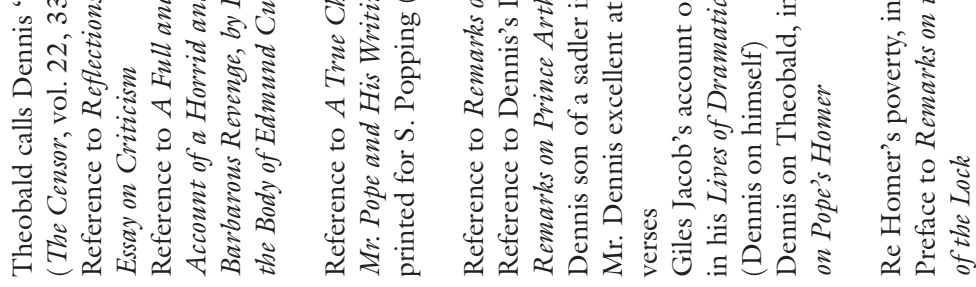

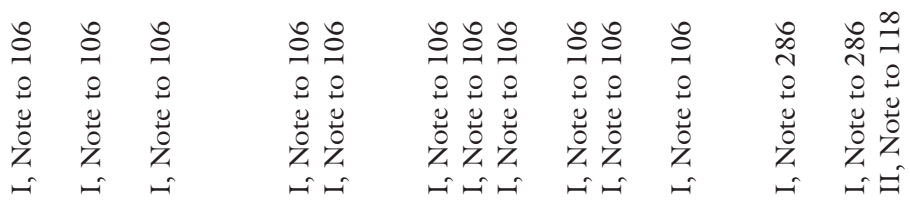

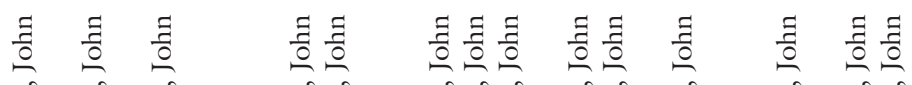

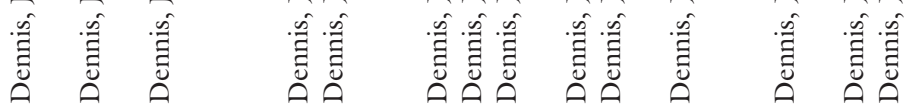




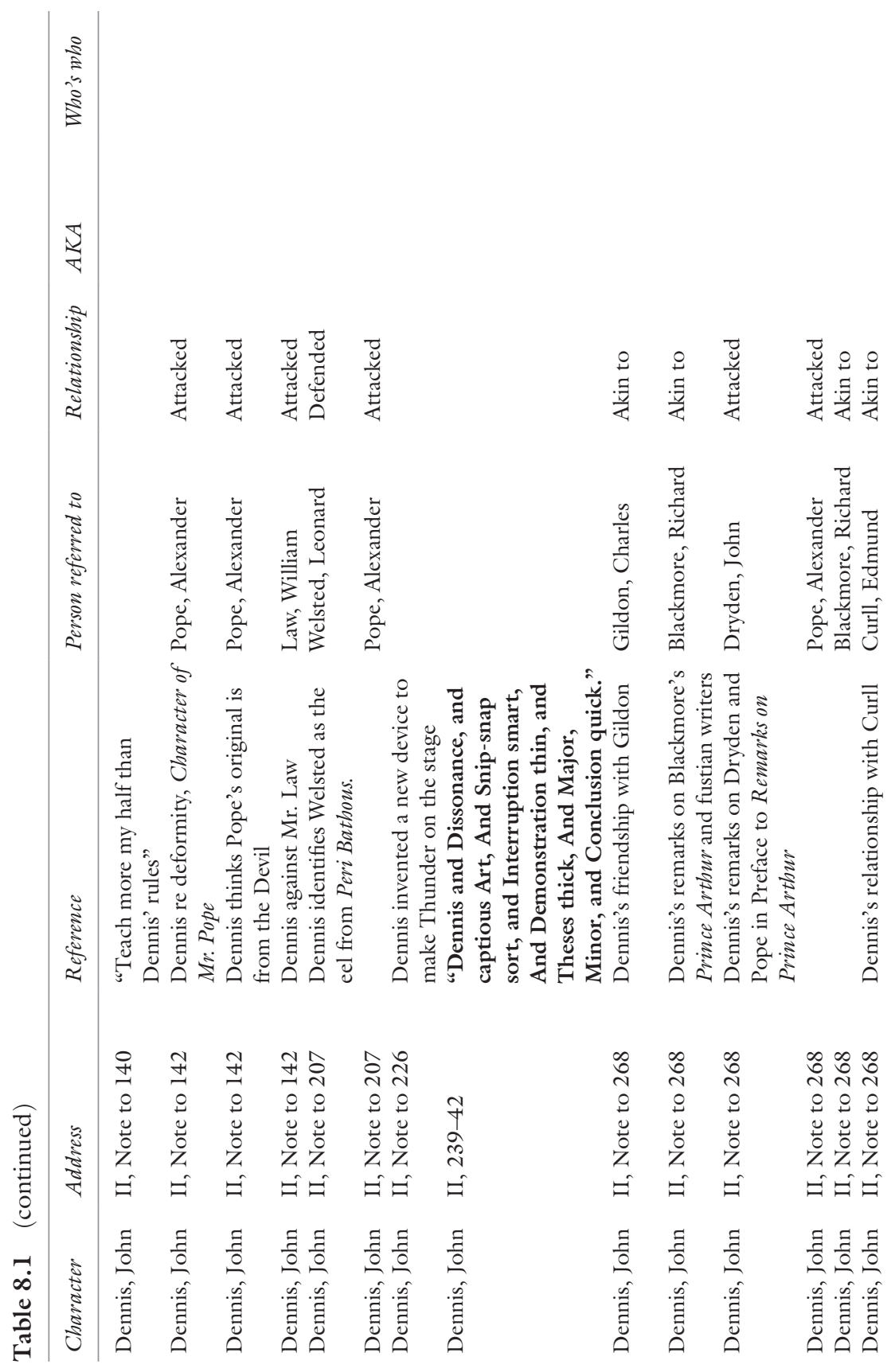




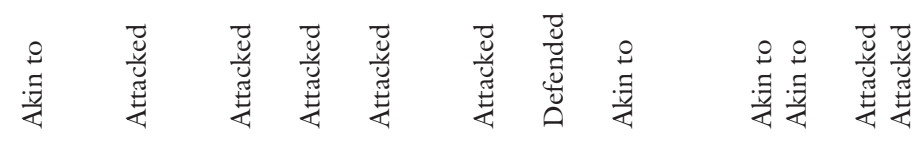

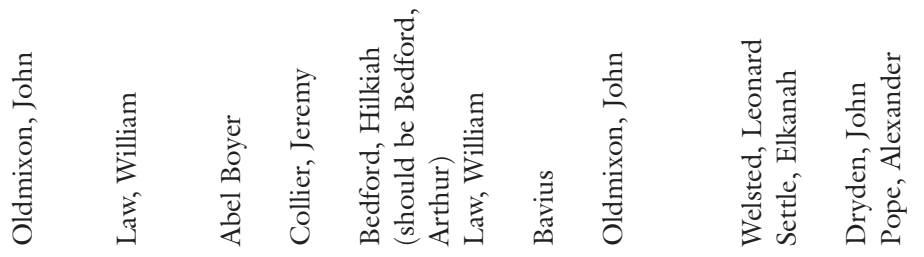

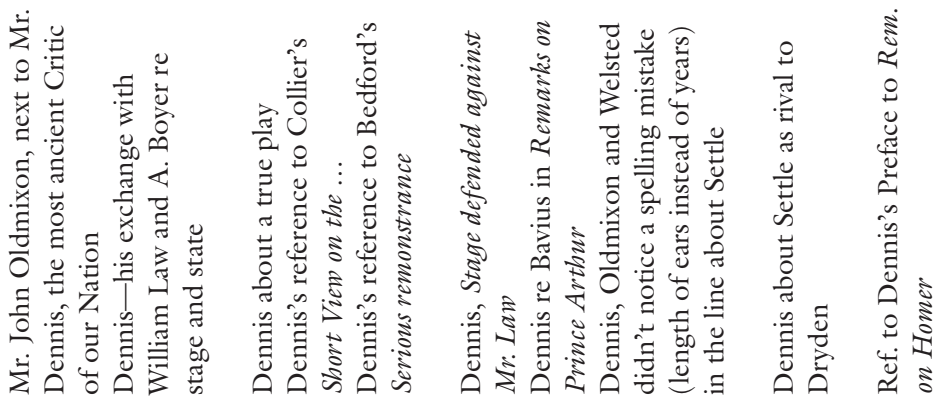

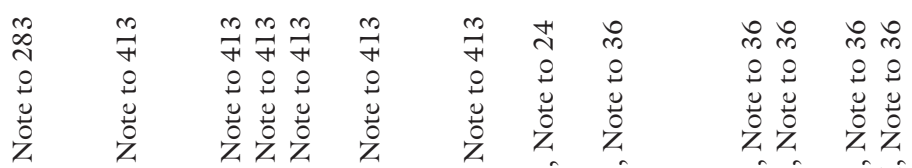

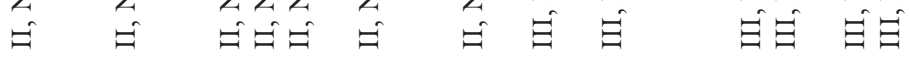

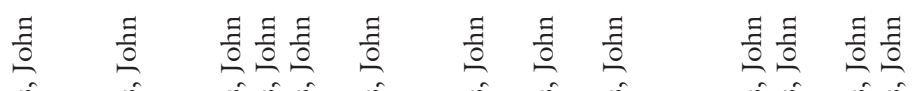

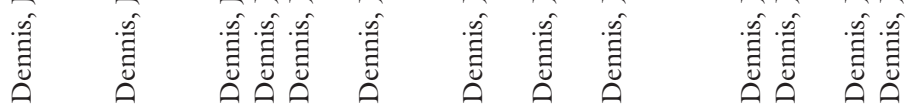




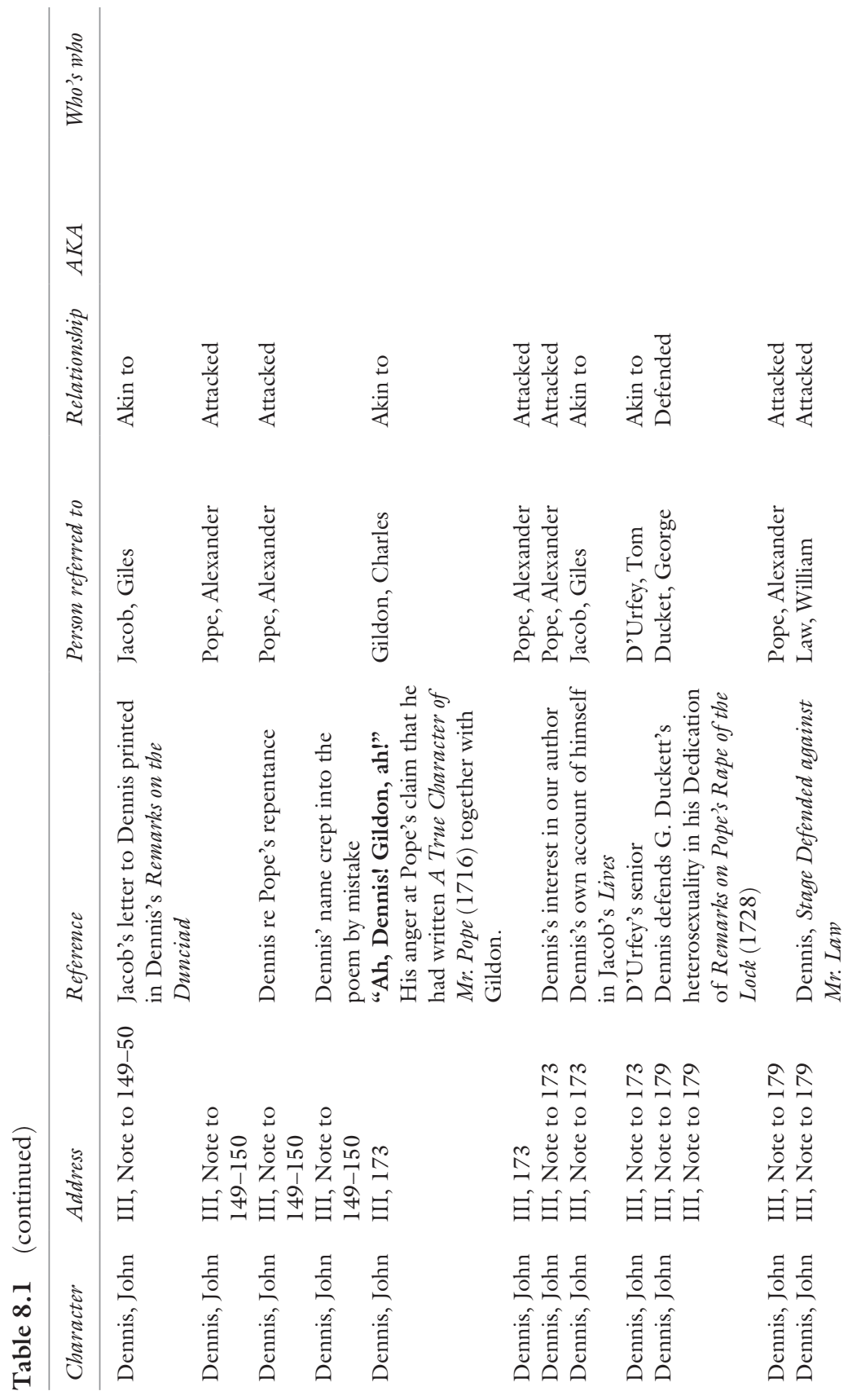




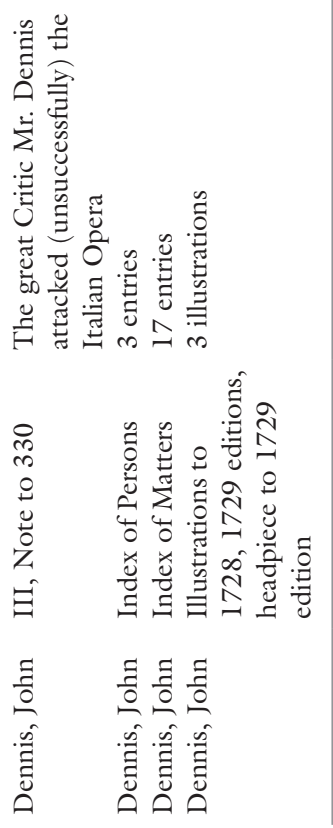




\section{BIBLIOGRAPHY}

A Collection of Miscellany Letters, Selected out of Mist's Weekly Journal. 1732. Vol. 2. London: Printed by N. Mist.

Algee-Hewitt, Mark. 2019. The Principles of Meaning: Networks of Knowledge in Johnson's Dictionary. In Edmondson and Edelstein, Networks of Enlightenment, 251-277.

Baird, Ileana. 2011. Visual Paratexts: The Dunciad Illustrations and the Thistles of Satire. In Book Illustration in the Long Eighteenth Century: Reconfiguring the Visual Periphery of the Text, ed. Christina Ionescu, 329-366. Newcastle upon Tyne: Cambridge Scholars Publishing.

- 2019. The Strength of Weak Ties: Eliza Haywood's Social Network in The Dunciad in Four Books (1743). ABO: Interactive Journal of Women in the Arts, 1640-1830 9 (2): 1-36. https://doi.org/10.5038/2157-7129.9.2.120.

Barabási, Albert-László. 2014. Linked: How Everything Is Connected to Everything Else and What It Means for Business, Science, and Everyday Life. New York: Basic Books.

Burrows, Simon, and Glenn Roe, eds. 2020. Digitizing Enlightenment: Digital Humanities and the Transformation of Eighteenth-Century Studies. Liverpool: Voltaire Foundation in association with Liverpool University Press.

Cannan, Paul D. 2015. John Dennis. In The Encyclopedia of British Literature 1660-1789, ed. Gary Day and Jack Lynch. Oxford: Oxford University Press.

Cuccuru, Kathrine. 2016. That 'Tremendous' Mr. Dennis: The Sublime, Common Sense, and Criticism. In Passions, Sympathy, and Print Culture: Public Opinion and Emotional Authenticity in Eighteenth-Century Britain, ed. Heather Kerr, David Lemmings, and Robert Phiddian, 105-121. London: Palgrave Macmillan.

Dennis, John. 1711. Reflections, Critical and Satyrical, upon a Late Rhapsody, Call'd, An Essay upon Criticism. London: Printed for Bernard Lintott.

- 1716. A True Character of Mr. Pope, and His Writings. In a Letter to a Friend. London: Printed for S. Popping.

- 1717. Remarks upon Mr. Pope's Translation of Homer, with Two Letters Concerning Windsor Forest, and the Temple of Fame. London: Printed for E. Curll.

- 1728. Remarks on Mr. Pope's Rape of the Lock. In Several Letters to a Friend. With a Preface Occasion'd by the Late Treatise on the Profound, and the Dunciad. London: Printed for J. Roberts.

- 1729. Remarks upon Several Passages in the Preliminaries to the Dunciad, Both of the Quarto and the Duodecimo Edition. And upon Several Passages in Pope's Preface to His Translation of Homer's Iliad. In Both Which Is Shewn the Author's Want of Judgment. With Original Letters from Sir Richard Steele, from the Late Mr. Gildon, from Mr. Jacob, and from Mr. Pope Himself, Which Shew the Falsehood of the Latter, His Envy, and His Malice. London: Printed for H. Whitridge.

Edelstein, Dan, and Chloe Summers Edmondson. 2019. Introduction: Historical Network Analysis and Social Groups in the Enlightenment. In Edmondson and Edelstein, Networks of Enlightenment, 1-20. 
Edmondson, Chloe, and Dan Edelstein, eds. 2019. Networks of Enlightenment: Digital Approaches to the Republic of Letters. Liverpool: Voltaire Foundation in association with Liverpool University Press.

Eve, Martin Paul. 2017. Close Reading with Computers: Signals, Parts of Speech, and David Mitchell's Cloud Atlas. SubStance 46 (3): 76-104. http://www. muse.jhu.edu/article/676240.

Fraser, Nancy. 1990. Rethinking the Public Sphere: A Contribution to the Critique of Actually Existing Democracy. Social Text (25/26): 56-80. https://doi. org/10.2307/466240.

Gay, John. 1717. Three Hours after Marriage: A Comedy. London printed; reprinted in Dublin by S. Powell.

Gladwell, Malcolm. 2000. The Tipping Point. How Little Things Can Make a Big Difference. New York: Back Bay Books.

Grafton, Anthony. 1997. The Footnote: A Curious History. Cambridge, MA: Harvard University Press.

Granovetter, Mark S. 1973. The Strength of Weak Ties. The American Journal of Sociology 78 (6): 1360-1380. http://www.jstor.org/stable/2776392.

Hanneman, Robert A., and Mark Riddle. 2005. Introduction to Social Network Methods. Riverside: University of California. https://faculty.ucr.edu/ rhanneman/nettext/C12_Equivalence.html.

Hooker, Edward N. 1940. Pope and Dennis. English Literary History 7 (3): 188-198. https://doi.org/10.2307/2871490.

Jacob, Giles. 1719-1720. The Poetical Register: Or, The Lives and Characters of All the English Dramatick Poets. With an Account of Their Writings. 2 vols. London: Printed by E. Curll.

- 1717. The Rape of the Smock: An Heroi-Comical Poem. London: Printed for R. Burleigh.

Johnson, Samuel. 1832. Pope. In The Works of Samuel Johnson, LL.D, vol. 2. New York: John Dearborn.

Law, William. 1726. The Absolute Unlawfulness of the Stage-Entertainments Fully Demonstrated. London: Printed for W. and J. Innys.

Lefebvre, Henry. 1995. The Production of Space. Trans. Donald Nicholson-Smith. Oxford: Blackwell Publishers.

Meulen, David L. Vander. 1991. Pope's Dunciad of 1728. A History and Facsimile. Charlottesville: University of Virginia Press.

Milgram, Stanley. 1967. The Small World Problem. Psychology Today 1 (1): 60-67. Moretti, Franco. 2005. Graphs, Maps, Trees: Abstract Models for a Literary History. New York: Verso.

Morillo, John. 2000. John Dennis: Enthusiastic Passions, Cultural Memory, and Literary Theory. Eighteenth-Century Studies 34 (1): 21-41. https://doi. org/10.1353/ecs.2000.0063.

Murphy, Avon Jack. 1984. John Dennis. Boston: Twayne Publishers.

Pearl, Lisa, Kristine Lu, and Anousheh Haghighi. 2017. The Character in the Letter: Epistolary Attribution in Samuel Richardon's Clarissa. Digital Scholarship in the Humanities 32 (2): 355-376. https://doi.org/10.1093/llc/fqw007. 
Peri Bathous, or The Art of Sinking in Poetry. 1727. In Miscellanies. The Last Volume. London: Printed for B. Motte.

Pope, Alexander. 1999. The Dunciad in Four Books. Edited by Valerie Rumbold. New York: Pearson.

1711. An Essay on Criticism. London: Printed for W. Lewis.

Rumbold, Valerie, ed. 2007. The Poems of Alexander Pope. Volume III: The Dunciad (1728) \& The Dunciad Variorum (1729). New York: Pearson.

Sherburn, George, ed. 1956. The Correspondence of Alexander Pope. Vol. 2. Oxford: Oxford Clarendon Press.

Smallwood, Philip. 2017. Petty Caviller or 'Formidable Assaillant'? Johnson Reads Dennis. The Cambridge Quarterly 46 (4): 305-324. https://doi. org/10.1093/camqtly/bfx025.

Sutherland, James R. 1942. Review of The Critical Works of John Dennis. The Review of English Studies 18 (69): 115-118. www.jstor.org/stable/509884.

Swift, Jonathan. 1704. A Tale of a Tub. Written for the Universal Improvement of Mankind. To Which Is Added, an Account of the Battel between the Antient and Modern Books in St. James Library. London: Printed for John Nutt.

The Popiad. 1728. London: Printed for E. Curll.

Weber, Harold. 1999. The 'Garbage Heap' of Memory: At Play in Pope's Archives of Dulness. Eighteenth-Century Studies 33 (1): 1-19. https://doi. org/10.1353/ecs.1999.0060.

Woloch, Alex. 2003. The One vs. the Many: Minor Characters and the Space of the Protagonist in the Novel. Princeton: Princeton University Press.

Zerby, Chuck. 2002. The Devil's Details. A History of Footnotes. New York: Simon \& Schuster.

Open Access This chapter is licensed under the terms of the Creative Commons Attribution 4.0 International License (http://creativecommons.org/licenses/ by $/ 4.0 /$ ), which permits use, sharing, adaptation, distribution and reproduction in any medium or format, as long as you give appropriate credit to the original author(s) and the source, provide a link to the Creative Commons licence and indicate if changes were made.

The images or other third party material in this chapter are included in the chapter's Creative Commons licence, unless indicated otherwise in a credit line to the material. If material is not included in the chapter's Creative Commons licence and your intended use is not permitted by statutory regulation or exceeds the permitted use, you will need to obtain permission directly from the copyright holder.

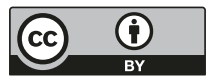

